\title{
Play-fairway Analysis for Geothermal Resources and Exploration Risk in the Modoc Plateau Region
}

Keywords: Geothermal exploration, play-fairway, fuzzy logic, faults, geothermometry

\author{
Drew L. Siler ${ }^{1 *}$, Yingqi Zhang ${ }^{1}$, Nicolas F. Spycher ${ }^{1}$, Patrick F. Dobson ${ }^{1}$, James S. McClain ${ }^{2}$, Erika \\ Gasperikova $^{1}$, Robert A. Zierenberg ${ }^{2}$, Peter Schiffman ${ }^{2}$, Colin Ferguson ${ }^{2}$, Andrew Fowler ${ }^{2}$, Carolyn Cantwell ${ }^{2}$ \\ ${ }^{1}$ Lawrence Berkeley National Laboratory, One Cyclotron Road, Berkeley, CA 94720 \\ ${ }^{2}$ University of California, Davis, One Shields Avenue, Davis, CA 95616 \\ *current affiliation U.S. Geological Survey, 345 Middlefield Rd, Menlo Park, CA 94025
}

ABSTRACT

The region surrounding the Modoc Plateau, encompassing parts of northeastern California, southern Oregon, and northwestern Nevada, lies at an intersection between two tectonic provinces; the Basin and Range province and the Cascade volcanic arc. Both of these provinces have substantial geothermal resource base and resource potential. Geothermal systems with evidence of magmatic heat, associated with Cascade arc magmatism, typify the western side of the region. Systems on the eastern side of the region appear to be fault controlled with heat derived from high crustal heat flow, both of which are typical of the Basin and Range. As it has the potential to host Cascade arc-type geothermal resources, Basin and Range-type geothermal resources, and/or resources with characteristics of both provinces, and because there is relatively little current development, the Modoc Plateau region represents an intriguing potential for undiscovered geothermal resources. It remains unclear however, what specific set(s) of characteristics are diagnostic of Modoc-type geothermal systems and how or if those characteristics are distinct from Basin and Range-type or Cascade arc-type geothermal systems. In order to evaluate the potential for undiscovered geothermal resources in the Modoc area, we integrate a wide variety of existing data in order to evaluate geothermal resource potential and exploration risk utilizing 'play-fairway' analysis. We consider that the requisite parameters for hydrothermal circulation are: 1) heat that is sufficient to drive circulation, and 2) permeability that is sufficient to allow for fluid circulation in the subsurface. We synthesize data that indicate the extent and distribution of these parameters throughout the Modoc region. 'Fuzzy logic' is used to incorporate expert opinion into the utility of each dataset as an indicator of either heat or permeability, and thus geothermal favorability. The results identify several geothermal prospects, areas that are highly favorable for the occurrence of both heat and permeability. These are also areas where there is sufficient data coverage, quality, and consistency that the exploration risk is relatively low. These unknown, undeveloped, and under-developed prospects are well-suited for continued exploration efforts. The results also indicate to what degree the two 'play-types,' i.e. Cascade arc-type or Basin and Range-type, apply to each of the geothermal prospects, a useful guide in exploration efforts.

\section{INTRODUCTION}

Conventional hydrothermal systems occur where subsurface permeability and heat are sufficiently high to drive fluid circulation. When hydrothermal circulation occurs at accessible depths, resources can be recovered and utilized for electricity generation and a variety of direct uses. Current installed geothermal electricity generation capacity in the United States is $\sim 3,525 \mathrm{MWe}, \sim 0.25 \%$ of the total domestic generation capacity (Geothermal Energy Association, 2015). Resource estimates suggest that there are $\sim 9,000 \mathrm{MWe}$ of generation capacity associated with identified hydrothermal systems and an additional 30,000 MWe exists from yet-to-bediscovered conventional hydrothermal systems (Williams et al., 2008), indicating that geothermal energy has the potential to constitute a significant portion of the future energy needs of the United States. This growth potential depends on discovery and efficient exploitation of yet-to-be-discovered resources, many of which may have no surface expression (blind geothermal systems). Here, we synthesize a variety of existing data in order to evaluate the potential for yet-to-be-discovered geothermal resources, and the risk associated with exploration for these systems, throughout the Modoc Plateau region. 
We employ play-fairway analysis to evaluate geothermal favorability and exploration risk. Play-fairway analysis is commonly utilized for defining the location and relative risk associated with oil and gas exploration. For a complete analysis, data indicating the location and extent of hydrocarbon source rock (under the appropriate temperature and pressure conditions), porous and permeable reservoir rocks, an impermeable seal with the appropriate geometry to trap hydrocarbons in the reservoir, and a pathway for migration of fluids from the source and into the reservoir are compared in a region of interest. This type of analysis indicates whether or not the area of interest exhibits the required conditions for hydrocarbons to have maturated in the source rock, migrated into the reservoir, and become trapped (Miller, 1982; Baker et al., 1986; Doust, 2010).

This project is one of a number of play-fairway evaluations that have been supported by the US Department of Energy's Geothermal Technologies Office (Weathers et al., 2015; Garchar et al., 2016) with the goal of adapting the play-fairway concept to geothermal exploration. Our adaption of play-fairway concepts to geothermal exploration relies on the spatial overlay of a number of datasets that are interpreted to be indicative of the parameters that are required for hydrothermal circulation. Heat and permeability are the two primary characteristics that are evaluated. Permeability is required in order to allow fluids to circulate to depth, acquire heat, and circulate back to exploitable depths in the shallow subsurface. Sufficient heat is required in order to heat the fluids and drive circulation along the permeable pathways. These two characteristics must occur collocated in space and coincident in time, in order for geothermal circulation to occur. For instance, neither a robust heat source collocated with an ancient, no longer permeable fault system, nor an active fault system local to an old magmatic intrusion that is too cold to serve as a heat source, represent prospective geothermal areas. This element of temporal and spatial coincidence adds a layer of complexity to adaptation of playfairway methodologies to geothermal exploration relative to oil and gas exploration. To extend the petroleum analogy, this would be similar to exploration for a petroleum reservoir that is actively being charged with hydrocarbons.

A wide variety of geologic, geophysical, geochemical, and temperature data are utilized as indicators or proxies for heat and permeability. We integrate these data using fuzzy logic (e.g., Zhang et al., 2009), a methodology for integrating disparate data using natural language, in order to incorporate expert opinion into the efficacy of each dataset for indicating the existence of permeability or heat. Fuzzy logic also provides an uncertainty range, the range of heat or permeability that is indicated by the data in a certain area. This range is used in assessment of risk associated with exploration at a particular location.

\subsection{Geothermal in the Modoc Plateau region}

The Modoc Plateau and surrounding area is a predominantly rural region of northeastern California, southern Oregon, and northwestern Nevada, centered on the Modoc Plateau physiographic province (Figure 1). In general, the Modoc study area is characterized by elevated heat flow (Williams and DeAngelo, 2011) and some 30 known geothermal systems as identified by thermal springs and wells (Faulds et al., 2006; Faulds et al., 2011) (Figure 1). The study area also contains six Known Geothermal Resources Areas (KGRAs), areas of potentially exploitable geothermal resources that were identified by the U.S. Geological Survey beginning in 1970 (Godwin et al., 1971; Burkhardt et al., 1980). The KGRAs are: Wendel-Amedee, Lake City-Surprise Valley, Lakeview, Summer Lake Hot Springs, Glass Mountain (also known as Medicine Lake), and Crump Geyser (Burkhardt et al., 1980). At Medicine Lake/Glass Mountain, geothermal exploration wells have confirmed the presence of a high temperature $\left(>260^{\circ} \mathrm{C}\right.$ ) geothermal resource (Hulen and Lutz, 1999; Cumming and Mackie, 2007a; Cumming and Mackie, 2007b).

There are five relatively small existing geothermal electricity generation facilities within the Modoc study area; San Emidio, NV (20.8 MWe), Wineagle, CA (0.7 MWe), Amedee, CA (1.6 MWe), Honey Lake, CA (1.5 MWe), and Paisley, OR (2.5 MWe) (Boyd et al., 2015). Additionally, there are currently operating direct use facilities, including space heating, greenhouses, and pools/spas in Canby, CA, Alturas, CA, Susanville, CA, Lakeview, OR, and Paisley, OR, and throughout Surprise Valley, CA (Battocletti, 2006; Merrick, 2006a; Merrick, 2006b; Merrick, 2009; Boyd et al., 2015). 


\subsection{Geology and tectonics of the Modoc Plateau region}

Geothermal activity in the Modoc Plateau study area is related to a combination of factors contributing to geothermal activity in the tectonic provinces that bound the area - the Cascade volcanic arc, the Basin and Range extensional province, and the Walker Lane (Figure 1). Geothermal activity in the Cascade Arc is a function of very young or active, shallow magmatism along the arc (Ingebritsen et al., 1989; Blackwell et al., 1990; Mariner et al., 1993; Ingebritsen et al., 2001). Conversely, geothermal systems in the Basin and Range are controlled by regionally high crustal heat flow and fault-related permeability, both of which are associated with active tectonic extension (Blackwell et al., 1999; Wisian and Blackwell, 2004; Faulds et al., 2006; Faulds et al., 2011). In the Walker Lane, and further south in the analogous Eastern California shear zone, geothermal systems are most commonly related to extensional steps in strike-slip fault systems, and have been shown to be associated with both regionally high heat flow and young magmatism (Duffield et al., 1980; Torgersen and Jenkins, 1982; Faulds et al., 2006; Faulds et al., 2011). In the Modoc Plateau study area, young and active magmatism, young and/or active extensional faulting, young and/or active dextral strike-slip faulting, and high (but amagmatic) crustal heat flow are all evident (Gay and Aune, 1958; Lydon et al., 1960; Walker, 1963; Walker and Repenning, 1965; Walker et al., 1967; Greene et al., 1972; Macleod and Sherrod, 1992; Saucedo and Wagner, 1992; Sherrod and Pickthorn, 1992; Crafford, 2010; Egger and Miller, 2011).

109

110

111

112

113

114

115

116

117

118

For the purpose of this study we concentrate primarily on tracking the distribution of the characteristics typical of Basin and Range-type and Cascade arc-type geothermal systems throughout the Modoc study area. Though strike-slip faulting is certainly evident, Walker Lane-type dextral shear is greatly diminished within the study area, relative to areas to the south (Kreemer et al., 2009; Kreemer et al., 2012). Additionally, Cape Mendocino, the de facto northern terminus of dextral shear along the Pacific-North American plate boundary, lies due west of the southern boundary of the study area, so we assume that Walker Lane-type tectonics have a relatively minor effect on Modoc area geothermal activity, relative to either Cascade arc-type or Basin and Range-type tectonics.

Figure 1. Map of the study area for Modoc Plateau play-fairway study.

\section{METHODOLOGY AND DATA}

Our analysis of the geothermal potential of the Modoc Plateau and surrounding area has three primary objectives: 1) quantify the potential for geothermal resources throughout the region, 2) determine the risk associated with exploration in the defined areas of high geothermal favorability, and 3) determine the most likely play-type (tectonically-hosted Basin and Range-type system, volcanic-hosted Cascade arc-type, or a transitional play-type between these two end-members), for each of the defined highly favorable areas. Two training sites, San Emidio for tectonically-hosted Basin and Range-type geothermal systems and Medicine Lake (a.k.a. Glass Mountain) for volcanically-hosted Cascade arc-type geothermal systems, both productiongrade geothermal resources, are used in order to determine 'play-type', and to calibrate our expert opinion on the utility of the various data types as indicators of heat and permeability.

Geothermal favorability, exploration risk, and play-type across the Modoc study area are evaluated via a grid of 12,960 square cells spanning the region, each $4 \mathrm{~km}^{2}$ in area. The $2 \mathrm{~km}-\mathrm{by}-2 \mathrm{~km}$ cell size was chosen as it approximates the general areal extent of many geothermal systems in the western United States. We found through multiple iterations of different sizes, that $4 \mathrm{~km}^{2}$ cells provide appropriate local scale resolution, while being large enough to incorporate multiple data points in areas of sparse data. Thirteen unique datasets are utilized as 'proxies' (or indicators) for the two primary geothermal characteristics, heat and permeability (Table 1). Information from each of these data sets is applied to the cell containing those data. We prefer this method to interpolation and/or extrapolation between data gaps, because both are not necessarily appropriate for many of the data sets that are used. For example, the location of a discrete feature like a mapped fault system or a hot spring, provide no information about areas between the location of that feature and the location of any other feature. So interpolation of fault density or spring chemistry between the two discrete measurements is meaningless. Instead, we assume a geothermal system size, i.e., $4 \mathrm{~km}^{2}$, and consider that all data within that cell are representative of the geothermal favorability within that cell. 


\subsection{Fuzzy Logic analysis}

The primary purpose of fuzzy logic is to formalize reasoning in natural language. For example, one of the many fuzzy rules to evaluate the favorability for permeability associated with faults can be formulated as:

If the total length of faults in a cell is LONG, and the faults are YOUNG, and the stress on the fault is HIGH, than the cell is FAVORABLE for permeability.

To be able to apply this rule, it is necessary to define "fuzzy numbers" for LONG, YOUNG, HIGH, and FAVORABLE. In fuzzy logic, these are called membership functions. The membership function, which is between one and zero, defines the membership of each cell the natural language rule, i.e. a cell with a very small total fault length would has a membership of one to SHORT and zero to LONG. The fuzzy numbers for each permeability proxy and each heat proxy are defined based on the distribution of the data and expert opinion regarding what the data indicate in terms of geothermal favorability (see Table 1 for membership function details for each dataset). These functions are discussed below for both permeability and heat attributes.

\subsection{Data: Permeability Proxies}

Seven different datasets are utilized as proxies for permeability: The total mapped fault length in each cell, the age of the youngest faulting, the stress state of mapped faults (dilation tendency and slip tendency), the existence of favorable structural settings, the strain rate, and the total seismic moment released during earthquakes.

\subsubsection{Total mapped fault length}

The total length of all mapped fault segments is summed in each cell, and we consider it a proxy for faultrelated permeability. Throughout the Modoc study area, cells with a higher total fault length are associated with higher geothermal favorability because there are more faults and a higher density of faults that may conduct geothermal fluids. Fault databases for Oregon, California, and Nevada from the Preliminary Integrated Geologic Map Databases for the United States (Ludington et al., 2005) are used (Figure 2). The database contains mapped faults compiled at 1:750,000 scale in California and 1:500,000 scale in Nevada and Oregon. Despite these differences, the scale of mapping does not impart a bias by state or by map scale to the total fault length applied to cells throughout the study area. The membership function for fault length (short, medium, and long) is defined based on the logarithm (base 10) of the total fault length in each cell (Table 1).

Figure 2. Fault data and geologic data compiled and utilized in the Modoc plateau area play-fairway study.

\subsubsection{Fault age}

In the Basin and Range province, correlation between Holocene faults and the location of known geothermal systems suggests that active faulting is an important control on permeability in geothermal systems. The Preliminary Integrated Geologic Map Databases for the United States used for calculation of fault length do not include fault age determinations. Therefore, the U.S. Geological Survey (USGS) Quaternary Fault and Fold Database (U.S. Geological Survey, 2006), in which faults are assigned ages, is used (Figure 2). Despite compilation at a finer map-scale $(1: 100,000$ for California and 1:250,000 for Nevada and Oregon) the Quaternary Fault and Fold Database contains fewer faults than the Preliminary Integrated Geologic Map Databases, because only those faults where a Quaternary or younger age determination can be reliably interpreted are included in the former. Again, despite the scale differences, the scale of mapping does not impart a bias by state or map scale to the fault age applied to cells throughout the study area. Faults are classified as <150 yrs (historic), <15,000 yrs (very-late Pleistocene), $<130,000$ yrs (late Pleistocene), $<750,000$ yrs (early-mid Pleistocene), and <1.6 Ma (early Pleistocene). The membership function (young, medium, and old) is defined based on a ranking from zero to one at intervals of 0.2 for the youngest faulting in each cell (Table 1).

\subsubsection{Fault stress state}


Critically stressed fault segments have a relatively high likelihood of acting as fluid flow conduits relative to fault segments that are not critically stressed (Sibson, 1994; Barton et al., 1995; Morris et al., 1996; Sibson, 1996; Barton et al., 1998; Ito and Zoback, 2000; Townend and Zoback, 2000; Zoback and Townend, 2001). The tendency of a fault segment to slip (slip tendency, the ratio of shear stress to normal stress on a surface) (Morris et al., 1996) or to dilate (dilation tendency, the ratio of all stresses acting normal to a given surface) (Ferrill et al., 1999) provide a quantitative indication of the likelihood of a certain fault segment to be critically stressed for either slip or dilation, and therefore to conduct fluids. Slip and dilation tendency values are calculated based on the fault geometry and a stress model, for each fault segment in the Preliminary Integrated Geologic Map Databases (Ludington et al., 2005) within the study area. Because dip is not well constrained or is unknown for most faults within the study area, fault dip is assumed to be $60^{\circ}$ for all faults. Though fault dips certainly vary, this assumed dip value represents the expected dip for normal faulting based on simple fault mechanics (Anderson, 1905). By assuming these reasonable values for all faults we can examine the relative variation in slip and dilation tendency between variable fault strikes throughout the study area. While, the use of these dip values means that the slip and dilation tendency values on a particular fault are not necessarily accurate, the relative slip and dilation tendency values along individual faults, and between different fault segments is a proxy for the along fault and fault-to-fault variation in permeability associated with tectonic stresses. Faults that are highly stressed are associated with high permeability and fluid flow favorability.

The tectonic stress within the study area is approximated based on regional published stress data and data from the World Stress Map (www.world-stress-map.org/) (Hickman et al., 1998; Hickman et al., 2000; RobertsonTait et al., 2004; Davatzes and Hickman, 2006; Heidbach et al., 2008; Hickman and Davatzes, 2010; Moeck et al., 2010; Moos and Ronne, 2010; Blake and Davatzes, 2011; Blake and Davatzes, 2012). From these data a smoothed $\mathrm{S}_{\mathrm{hmin}}$ (minimum horizontal stress tensor) azimuthal variation field, which ranges from $\mathrm{S}_{\mathrm{hmin}}$ azimuth $\approx 080^{\circ}$ to $118^{\circ}$, is generated. Inversions of earthquake focal mechanisms suggest that normal faulting is predominant throughout the Modoc region, relative to strike-slip and thrust faulting events. We therefore applied a normal faulting stress regime, where the vertical stress $\left(\mathrm{S}_{\mathrm{v}}\right)$ magnitude is larger than the magnitude of the maximum horizontal stress $\left(\mathrm{S}_{\mathrm{Hmax}}\right)$, which is larger than the magnitude of the minimum horizontal stress $\left(\mathrm{S}_{\mathrm{v}}\right.$ $>\mathrm{S}_{\mathrm{H} \max }>\mathrm{S}_{\mathrm{hmin}}$ ). Based on visual inspection of the limited stress magnitude data throughout the western United States, we apply a stress model such that the magnitude $S_{\mathrm{hmin}} / \mathrm{S}_{\mathrm{Hmax}}=0.5$ and $\mathrm{S}_{\mathrm{hmin}} / \mathrm{S}_{\mathrm{v}}=0.4$, which are consistent with complete and partial stress magnitude determinations based on borehole imagery from Desert Peak geothermal field, NV, the Fallon, NV area, and Dixie Valley geothermal field, NV (Walker and Repenning, 1965; Hickman et al., 1998; Hickman et al., 2000; Robertson-Tait et al., 2004; Davatzes and Hickman, 2006; Hickman and Davatzes, 2010; Blake and Davatzes, 2011). The membership function for fault stress (high, medium, and low) is defined based on maximum slip tendency and the maximum dilation tendency calculated in each cell (Table 1).

We recognize that the Pyramid Lake fault, Honey Lake fault, Warm Springs Valley fault, in the southern part of the Modoc study area, and many of their subsidiary faults, show evidence for Walker Lane-type dextral strike-slip faulting in the Quaternary (e.g., Faulds et al., 2005; Faulds and Henry, 2008). Both published mapping and simple fault mechanics suggests that the dip of these predominantly dextral and dextral-normal faults is likely to be steeper than $60^{\circ}$. Our regional assumption of a normal faulting stress regime and $60^{\circ}$ dip is therefore invalid for these faults and the slip tendency and dilation tendency values that are calculated for these faults probably misrepresent the stress state of the predominantly strike-slip faults. However, in the absence of fault dip and/or sense of slip data throughout the study area, we assume a normal faulting stress regime, which is the predominant sense of slip from earthquake focal mechanisms, and $60^{\circ}$ fault dip are representative of the study area.

\subsubsection{Structural Setting}

Throughout the Basin and Range and around the world, it is well recognized that geothermal systems occur at discontinuities along faults (Curewitz and Karson, 1997; Faulds et al., 2006; Hinz et al., 2008; Faulds et al., 2010; Hinz et al., 2010; Faulds et al., 2011; Hinz et al., 2011; Wallis et al., 2012; McNamara et al., 2015). Horse-tailing fault terminations, fault intersections, fault step-overs, and accommodation zones are the most common structural settings in the Great Basin and host the majority of known geothermal systems (Faulds et 
al., 2011b, 2010, 2006; Hinz et al., 2011, 2010, 2008). Based on the two fault databases, the Modoc study area is visually analyzed for the occurrence of these structural geometries (Figure 2). A circle with a radius of $1 \mathrm{~km}$ is utilized to mark all favorable structural settings, and a total of 138 favorable settings were chosen. A binary membership function (favorable setting or unfavorable setting) is used for the fuzzy logic analysis (Table 1).

\section{Table 1. Cell selection and membership function details for Modoc area heat and permeability data.}

\subsubsection{Strain: Regional strain-rate and seismic moment magnitudes}

Spatial correlations between high-temperature geothermal systems and elevated strain-rate (Faulds et al., 2012) suggest that active tectonism is an important factor in generating and maintaining the permeable pathways necessary for geothermal circulation. Regionally smoothed deformation rates, calculated based on geodetic data and quantified as the $2^{\text {nd }}$ invariant of the strain-rate tensor (Kreemer et al., 2012), are used as one indicator for strain. The membership function for strain-rate (high, medium, and low) is defined based on the logarithm (base 10) of the mean strain-rate in each cell (Table 1).

The magnitudes of earthquakes, as recorded since 1970 are compiled from the Pacific Northwest Seismic Network (http://www.pnsn.org/), the Northern California Seismic Network (http://www.ncedc.org/ncsn/), and the Nevada Seismic Network (http://www.seismo.unr.edu/) (Figure 2). The seismic moment for each event is calculated (Aki and Richards, 2002) and the summed seismic moment in each cell is utilized as a second proxy for strain. The membership function for seismic moment (high, medium, and low) is defined based on the logarithm (base 10) of total seismic moment in each cell (Table 1).

\subsection{Data: Heat Proxies}

Six different datasets are utilized as proxies for heat: the age and composition of Quaternary and younger volcanism, four different types of subsurface heat/temperature measurements (heat flow, temperature gradient, measured well temperature, and smoothed heat flow interpolation), and geothermometry data from three different chemical geothermometers.

Additionally, eight different geochemical ratios, each indicative of geothermal activity, from more than 30,000 water chemistry analyses, were examined for inclusion in the study. However, these water chemistry data were found to be too sparsely distributed, and the reliability of the analyses too uncertain to include in our fuzzy logic analysis. Thirty six ${ }^{3} \mathrm{He} /{ }^{4} \mathrm{He}$ measurements (Kennedy and van Soest, 2007; Siler and Kennedy, 2016) are also available in the Modoc study area, but these data were also found to be too sparsely distributed for inclusion in the fuzzy logic analysis. If appropriate data are available, multicomponent equilibrium geothermometry using iGeoT (Spycher et al., 2014; 2016) is utilized to constrain the deep reservoir temperature at the yet-to-be-recognized areas of high geothermal potential that are indicated by this work.

\subsubsection{Quaternary Volcanism}

The age and composition of Quaternary volcanic deposits based on geologic maps (Gay and Aune, 1958; Lydon et al., 1960; Walker, 1963; Walker and Repenning, 1965; Walker et al., 1967; Greene et al., 1972; Macleod and Sherrod, 1992; Saucedo and Wagner, 1992; Sherrod and Pickthorn, 1992; Crafford, 2010; Egger and Miller, 2011) are used as proxies for heat related to young magmatism. Volcanism older than Quaternary age is not considered, as subsurface intrusions related to such volcanic material are unlikely to have retained enough heat to drive a modern geothermal system. Mapped mafic and felsic volcanic and intrusive units are also differentiated. The youngest mapped intrusive and volcanic material is interpreted to correlate with the highest geothermal potential, and we assume that geothermal potential decreases with increasing age. Mapped felsic materials are assumed to have larger volumes of associated intrusive rocks in the subsurface relative to mafic material, and thus young felsic material is interpreted to be associated with a higher local geothermal potential than contemporary mafic material. The membership functions for heat associated with Quaternary volcanism (high, medium, and low) is defined from zero to one, one associated with youngest felsic volcanism 
with progressively smaller numbers corresponding to more mafic and older volcanism. Zero associated with no volcanism (Table 1).

\subsubsection{Subsurface Heat}

Heat flow and temperature gradient data per well, and maximum bottom hole temperature in wells are compiled from the USGS heat flow database (Williams and DeAngelo, 2011), and the state geothermal well databases from Oregon

\section{Figure 3. Heat flow, well, geochemistry, and He isotope data used in the Modoc area play-fairway study.}

(http://www.oregongeology.org/sub/gtilo/), California (http://www.conservation.ca.gov/dog/geothermal/Pages /Index.aspx) and Nevada (http://www.nbmg.unr.edu/geothermal/Data.html). We consider a per-well measurement of heat flow to be the most reliable data type for defining heat associated with geothermal circulation. If a heat flow value is not available, but a temperature gradient is available, a heat flow value is derived based on the temperature gradient and a linear regression of the available heat flow and temperature gradient data throughout the Modoc study area. If temperature gradient data are not available, the interpolated and smoothed heat flow value from the USGS heat flow map (Williams and DeAngelo, 2011) is applied to each cell.

The highest bottom hole temperature divided by well depth is also used as an indicator of subsurface heat. While bottom hole temperature divided by well depth is not directly comparable to a measurement of heat flow or temperature gradient, relatively high temperatures in relatively shallow wells may indicate convective fluid circulation at shallow depths. At locations where no deep subsurface heat data are available, bottom hole temperature divided by well depth therefore serves as a proxy for the presence of shallow fluid convection. The membership function for subsurface heat (high, medium, low) is defined based on the histogram of the combined heat-flow, derived heat flow, and smoothed heat flow data set. The details of the natural language used for the heat data is explained below.

\subsubsection{Geothermometry data}

$\mathrm{The} \mathrm{Na} / \mathrm{K}, \mathrm{SiO}_{2}$ (quartz, conductive), and $\mathrm{K} / \mathrm{Mg}$ geothermometers (Fournier and Potter II, 1982; Giggenbach, 1988) are calculated from a compilation of publically available water chemistry data (Waring, 1915; Livingstone, 1963; Garrels and Mackenzie, 1967; Duffield and Fournier, 1974; Reed, 1975; Eugster and Hardie, 1978; Nehring and Mariner, 1979; Bliss and Rapport, 1983; Clawson et al., 1986; Eliot Allen \& Associates and Geo-Mat Inc., 1986; Westcot et al., 1990; Mariner et al., 1993; Sladek et al., 2004; Barker et al., 2005; Costa, 2008). The $\mathrm{Na} / \mathrm{K}$ geothermometer value is given preference as these data are available throughout the study area, and it is not affected by dilution or evaporative concentration. The $\mathrm{Na} / \mathrm{K}$ geothermometer, however, can be affected by the equilibration of thermal fluids with silicates other than feldspars, and by external sources of $\mathrm{Na}$ and $\mathrm{K}$ such as mixing with alkali lake water or leaching of evaporite minerals (e.g., Cantwell and Fowler, 2014; Peiffer et al., 2014; Fowler et al., 2015). Data for the calculation of the $\mathrm{SiO}_{2}$ (quartz, conductive) geothermometer and the $\mathrm{K} / \mathrm{Mg}$ geothermometer are relatively sparse within the study area, so these data are not used in the fuzzy logic analysis. The membership function for subsurface heat based on the $\mathrm{Na} / \mathrm{K}$ geothermometer (high, medium, low) is defined based on the histogram of the highest temperature in each cell (Table 1).

\subsection{Data: Marketability proxies}

In addition to the geothermal potential and risk of a particular geothermal prospect, infrastructure, market, and economic factors also effect whether or not a potential resource is conducive for development. We consider land status, the distance to existing high voltage transmission, and population density as the most important factors controlling the marketability of geothermal resources throughout the Modoc area. Potential geothermal prospects that are relatively near to existing transmission corridors have a higher likelihood of development because construction of expensive new transmission lines is not required. Transmission data are obtained from Geothermal Prospector (https://maps.nrel.gov/geothermal-prospector/), the National Renewable Energy Laboratory online geothermal data tool. The distance from each cell to $100 \mathrm{kV}$ transmission lines is calculated. 
Land status data were also obtained from Geothermal Prospector. We consider all land restricted by the National Forest Service, the Bureau of Land Management, as well as existing Areas of Critical Environmental Concern as off limits to geothermal development.

Direct use of geothermal fluids is prevalent throughout the Modoc study area, most commonly in the small towns and communities. It is prudent, therefore to consider direct use as a viable geothermal application in exploration of the region. The Modoc area is predominantly sparsely populated and we suggest that direct use is most feasible in the more densely populated towns and communities. This is certainly true of the existing direct use facilities in the Modoc area, where geothermal resources are used for district heating and other municipal purposes including pools and spas. Direct use is certainly possible in areas of low population density, for example, aquacultural and agricultural uses are not confined to populated areas. However, transportation and supply chain costs may become significant in these more remote areas. Thus, population density serves as an effective, though imperfect, proxy for the marketability of a potential direct use project in the Modoc area. From 2010 US census data, population density was calculated for each census tract in the Modoc study area (Figure 4). These marketability data are not included in the fuzzy logic analysis, but are incorporated in the subsequent evaluation of the highly favorable/low risk areas revealed by the play-fairway methods.

\subsection{Fuzzy Logic Evaluation: Permeability}

Figure 5 shows how membership functions are defined for each fuzzy number representing fault length (L). Xaxis is the logarithm base10 of a fault length. The $\mathrm{Y}$ axis defines the membership function. A cell with a total fault length logarithm $\left(\log _{10}(\mathrm{~L})\right)$ between 0 and 3.0 is defined as "short". The membership function is one for a fault with $\log _{10}(\mathrm{~L})$ between 0 and 3.0 (i.e. full membership in "short"), and the membership function for "medium" and "long" is zero for a fault with $\log _{10}(\mathrm{~L}) \geq 3.0$ (no membership in "long" or "medium"). The "medium" membership function is defined by $3.0 \leq \log _{10}(\mathrm{~L}) \leq 4.0$; and the "long" membership function by $\log _{10}(\mathrm{~L}) \geq 4$.0. Based on these definitions, a degree of membership for each cell in the fuzzy set is calculated. For example, if a cell has $\log _{10}(\mathrm{~L})=3.25$, the membership to "short" is 0.5 ; the membership to "medium" is 0.5 , and the membership to "long" is 0 . See Table 1 for description of how the membership functions are defined for each dataset.

A similar approach is used for the stress state of faults, structural setting type, seismicity, and strain rate. A total of 41 rules are defined to infer the favorability for permeability based on the seven input data sets. Rules are then combined using the standard inference method "mamdani", provided by Matlab. The output is an aggregated membership function which, in the end, is "defuzzified" by an averaging process. The centroid $F_{m}$ of the "defuzzified" membership function corresponds to the favorability for permeability in that cell. The difference between the upper $\left(F_{u}\right)$ and lower $\left(F_{1}\right)$ bound of the "defuzzified" membership function represents the range of favorability values possible in each cell. This is used to define the uncertainty. A cell that shows a large range between $F_{u}$ and $F_{l}$, while possibly favorable, has high uncertainty and a greater exploration risk as a result of this wide range.

Figure 5. Membership functions for fuzzy numbers representing fault length.

\subsection{Fuzzy Logic Evaluation: Heat}

The evaluation of heat is different from the evaluation of permeability because the quality of each type of data is clearly different. The USGS smoothed heat flow map (Williams and DeAngelo, 2011) is not ideal for evaluation of subsurface heat related to exploration for geothermal systems because convective heat flow measurements are smoothed out in the regional interpolation. The map is generated with a cap on the maximum heat flow value of $120 \mathrm{~mW} / \mathrm{m}^{2}$ to minimize the influence of convective high heat flow associated with hydrothermal systems (Williams and DeAngelo, 2011). This smoothed map is the only dataset with complete coverage of the study area. As stated above, we consider a per-well measurement of heat flow (the original unsmoothed data) to be the most reliable indicator of subsurface heat. If per-well heat flow measurements are 
available, these values are evaluated based on the distribution of the heat flow data throughout the study area, with a relatively small uncertainty range. If a temperature gradient measurement is available, a heat flow value is derived based on a linear regression of available temperature gradient and heat flow data in throughout the Modoc area. If no such data are available, heat is evaluated based on a combination of the regional smoothed heat flow map (Williams and DeAngelo, 2011), maximum measured well temperature divided by well depth, and geothermometry data; and the corresponding evaluation is assigned a relatively large uncertainty range. The locations with only smoothed heat flow are assigned the largest uncertainty range.

To construct the final geothermal favorability map (Figure 8), we defined five fuzzy numbers each for permeability and heat, and nine fuzzy numbers for the final favorability. Twenty-six rules are used to evaluate the overall geothermal potential for each cell. For each cell in the Modoc study area, we calculated a geothermal favorability score from the centroid $\left(\mathrm{F}_{\mathrm{m}}\right)$ of the aggregated membership function and an uncertainty (risk) from the difference between the upper $\left(\mathrm{F}_{\mathrm{u}}\right)$ and lower $\left(\mathrm{F}_{\mathrm{l}}\right)$ bounds.

\subsection{Play-type determination}

Play-type is determined by analyzing the similarity of each cell in the study area to the two end-member training sites at Medicine Lake and San Emidio. Datasets showing favorable values for each training site are considered to be diagnostic of that play-type. The absolute value of the difference between the value of each cell at the training site and the value of each cell throughout the Modoc study area are calculated and summed, thus yielding a measure of difference of each cell from both the San Emidio and Medicine Lake training sites. Any yet-to-be-discovered geothermal resources in cells with a high similarity (low difference) to San Emidio, for example, are likely to be tectonically-hosted Basin and Range-type systems, while resources in cells similar to Medicine Lake are likely to resemble Cascade arc-type, volcanically-hosted systems. High geothermal favorability cells that bear resemblance to both Medicine Lake and San Emidio may represent a transitional type of geothermal system, where characteristics of both volcanically- and tectonically-hosted geothermal have an effect on geothermal circulation.

\section{RESULTS}

A high density of young and well-oriented faults and favorable structural settings define high favorability for permeability in the southeastern part of the study area, particularly southeast of Susanville, CA and west of San Emidio (Figure 6). This area also exhibits relatively high strain-rates and a relative abundance of seismicity.

\section{Figure 6. Permeability favorability and risk (indicated by the difference between the lower and upper bound of favorability) for the Modoc study area}

There is also an area of high permeability favorability along the eastern side of Eagle Lake, CA, to the northwest of Susanville, controlled by a high density of young and well-oriented faults and favorable structural settings. Another high permeability favorability area lies southeast of the Lassen KGRA brought on by young and well-oriented faulting and a very abundant seismicity since 1970. Permeability favorability is generally lower in the northern part of the Modoc study area, where Quaternary faults are less prevalent and strain rates are lower (Figures 2 and 6). However, relatively high permeability favorability occurs in several areas, including along the western side of Surprise Valley, CA, around the town of Lakeview, OR, south of the town of Alturas, CA, within and to the southeast of the Crump Geyser KGRA, and east of the town of Paisley, OR. Permeability risk tends to be relatively high in areas where young faults (favorable) are prevalent, but are not well oriented for slip or dilation tendency (unfavorable) or alternatively where favorably oriented faults are older. These data indicate a relatively large range in permeability favorability and this risk is higher (Figure 6).

Broad zones of very high favorability for heat occur at Medicine Lake, around Lakeview, OR, and in two areas to the north/northwest of San Emidio. The broad extent of these large, high heat favorability areas are primarily controlled by the interpolated and smoothed regional heat flow values from the USGS heat flow map (Williams 
and DeAngelo, 2011). However, these areas all contain wells with high, apparent convective, heat flow as well. Uncertainty is relatively high throughout the broad areas because these they are primarily defined by the interpolated heat flow map, which carries relatively high uncertainty relative to the other heat proxies (Figure 7). However, within the broad areas of high heat favorability, cells containing discrete high per-well measurements of heat flow have very low uncertainty. Several smaller areas of high heat favorability occur at San Emidio, NV (with very low risk), Susanville, CA, Lake City, CA, and in and to the south of Vya, NV. The high heat favorability in these areas is controlled by direct measurements of high heat flow and temperature gradient measurements in wells.

Figure 7. Heat favorability and risk (indicated by the difference between the lower and upper bound of favorability) for the Modoc study area

\subsection{Total geothermal favorability}

The highest geothermal favorability and lowest risk in the Modoc study area is found at San Emidio (Figures 8 and 9). High favorability with moderate risk is found at known and developed geothermal areas at San Emidio, NV (power plant), Lakeview, OR (multiple direct use operations), Lake City, CA (direct use), Susanville, CA (direct use), and Wendel, CA (power plant).

Many cells displaying moderate favorability with moderate risk occur in both developed/well-known areas and relatively unknown/undeveloped areas. Those that are developed and/or well-known include Medicine Lake, CA (production-grade geothermal, but on protected land), Susanville, CA (direct use), Cedarville, CA (direct use), Crump Geyser (KGRA), and Litchfield in the Wendel-Amedee KGRA (no longer operating direct use facility) (Boyd et al., 2015).

There are five newly identified, relatively unknown/undeveloped areas with moderate- favorability, moderaterisk. These are Boulder Flat, NV, Bonham Ranch, NV, Eagle Lake, CA, Vya, NV, and New Pine Creek, OR (Figures 8 and 9). Each is discussed in detail below.

Figure 8. Total geothermal favorability and exploration risk for the Modoc study area

Figure 9. Geothermal favorability vs. exploration risk. Black and colored dots represent the exploration risk and geothermal favorability of every cell in the Modoc study area. Red dots fall in the training sites, ML for Medicine Lake and SE for San Emidio. Green dots are known and/or exploited geothermal systems and KGRAs, Lv for Lakeview, LC for Lake City, Sv for Susanville, Lf for Litchfield, Cv for Cedarville, CG for Crump Geyser. Blue dots are relatively favorable, relatively low risk undeveloped/unknown sites as identified by this study, BR for Bonham Ranch, BF for Boulder Flat, NPC for New Pine Creek, and Vy for Vya.

\subsection{Geothermal prospects identified through play-fairway analysis}

\subsubsection{Boulder Flat, NV}

The Boulder Flat area lies $\sim 60 \mathrm{~km}$ south-southeast of the town of Alturas, CA. The Boulder Flat area is characterized by Oligocene to Miocene basaltic to rhyolitic lava flows and Tertiary to Quaternary sedimentary rocks (Crafford, 2010; Egger et al., 2014). The area contains several well-oriented faults of unknown age. All faulting of known age adjacent to Boulder Flat is very-late Pleistocene or younger $(<15,000 \mathrm{yrs})$, suggesting that there is active tectonism in the area. However, strain rates are low and there has been no recorded seismicity in the area since 1970 . Shallow temperature gradient wells $(<30 \mathrm{~m})$ in the USGS heat flow database have very high temperature gradients, as high as $\sim 4000{ }^{\circ} \mathrm{C} / \mathrm{km}$. These temperature gradients are almost certainly convective rather than conductive, and thus no heat flow calculations have been made on any of the 
wells in Boulder Flat. These very high temperature gradients may be indicative of shallow geothermal circulation.

Measured temperatures reported for surface and subsurface waters sampled at Boulder range from 9 to $21^{\circ} \mathrm{C}$. Geochemical analyses of these waters are mostly incomplete. The $\mathrm{pH}$ is reported in only 5 out of $\sim 30$ analyses, and indicates a strongly alkaline character. Most of these waters are quite dilute $(\sim 5-13 \mathrm{mg} / \mathrm{L} \mathrm{Cl})$, but three samples from Boulder Flat are significantly more concentrated (101-150 mg/L Cl), although with lower silica concentrations than the dilute waters. Quite inconsistent traditional geothermometry results are obtained with these waters $\left(\mathrm{SiO}_{2}\right.$ quartz temperatures of $96^{\circ}$ to $125^{\circ} \mathrm{C}$ and $\mathrm{Na} / \mathrm{K}$ temperatures of 127 to $\left.>300^{\circ} \mathrm{C}\right)$. This is expected given that most of these waters do not show a clear mature thermal character. Waters with lowest $\mathrm{Mg}$ concentrations $(0.1 \mathrm{mg} / \mathrm{L})$ tend to show the highest silica concentrations. These waters, which are the most likely to have a thermal imprint, are shown as the group of labeled points displaying the highest $\mathrm{Na} / \mathrm{K}$ temperatures on Figure 10a (on the lower dashed arrow). The labeled point falling on the upper dashed arrow (Figure 10a) corresponds to one of the more concentrated waters, although still with a somewhat low $\mathrm{Mg}$ concentration $(0.8 \mathrm{mg} / \mathrm{L})$; this point yields the lowest $\mathrm{Na} / \mathrm{K}$ temperature $\left(\sim 127^{\circ} \mathrm{C}\right)$. An attempt was made to estimate deep temperatures by optimized multicomponent equilibrium geothermometry using iGeoT (Spycher et al., 2014; 2016) to take into account the effect of potential dilution, degassing, and calcite precipitation potentially affecting these fluids. The mineral equilibration temperatures resulting from this analysis average $\sim 198^{\circ} \mathrm{C}$ for the dilute waters and $139^{\circ} \mathrm{C}$ for the more concentrated water (Figure 10b). These calculated temperatures, however, should be considered quite uncertain (and possibly non-unique) given the lack of both mineralogical data and complete geochemical analyses.

Population density at Boulder Flat is very low. The area with the highest geothermal favorability does not lie on land that is protected from development. A high voltage $(100 \mathrm{kV})$ transmission corridor passes $\sim 5 \mathrm{~km}$ to the east of the highest temperature area.

Figure 10. (a) Na-K-Mg geothermometry plot for Boulder Flat waters: most samples appear unsuitable for geothermometry analyses. (b) Multicomponent equilibrium geothermometry with the waters shown as labeled points in (a) accounting for effects of dilution, $\mathrm{CO}_{2}$ exsolution, and precipitation of calcite; results of traditional geothermometers applied to the reconstructed fluid are also shown.

\subsubsection{Eagle Lake, CA}

Eagle Lake, CA lies $20 \mathrm{~km} \mathrm{NW}$ of the town of Susanville, CA. Eagle Lake is characterized by Holocene basaltic lava flows, Pliocene to Pleistocene basaltic to andesitic lava flows, Mesozoic granitic rocks, and Quaternary sediments (Lydon et al., 1960; Colie, 2003). Faults in the Eagle Lake area are densely spaced, well oriented for slip and dilation, though not particularly young; predominantly late Pleistocene (130,000 yrs) or younger (Colie, 2003). At two locations along the eastern shore of Eagle Lake, late-Pleistocene faults appear to step to the right, in two favorable structural discontinuities. Strain rates are relatively high, although there has been no seismicity recorded at Eagle Lake since 1970. Heat flow and temperature gradient data at Eagle Lake are limited; a relatively low heat flow of $47 \mathrm{~mW} / \mathrm{m}^{2}$ has been calculated for one well in the Eagle Lake area.

Our geochemical data compilation for this area includes a large number of groundwater analyses lacking important parameters such as $\mathrm{pH}$, temperature, silica concentration, and other parameters necessary to confirm a potential thermal component. The measured fluid temperatures in these samples do not exceed $\sim 26^{\circ} \mathrm{C}$. Traditional geothermometry indicates temperatures as high as $350^{\circ} \mathrm{C}(\mathrm{Na} / \mathrm{K})$, though these values do not agree well with $\mathrm{SiO}_{2}$ or $\mathrm{K} / \mathrm{Mg}$ geothermometers, which are as high as $95^{\circ} \mathrm{C}$ and $123^{\circ} \mathrm{C}$, respectively. Most samples for which $\mathrm{pH}$ is available are alkaline, $\mathrm{pH}$ between 8.4 and 9.8, with $\mathrm{Ca}-\mathrm{Mg}-\mathrm{CO}_{3}$ and $\mathrm{Na}-\mathrm{HCO}_{3}$ compositions reflecting evaporative concentration of waters from Eagle Lake, which is endorheic (closed drainage basin) and therefore the only recharge to groundwater in the area. As such, most (if not all) of the available groundwater analyses are not amenable to traditional solute geothermometry analyses. A few high $\mathrm{Na}+\mathrm{K}, \mathrm{low}-\mathrm{Mg}$ samples have been reported (points with labels shown on Figure 11a), which are more likely to reflect some thermal 
component. The lowest-magnesium sample yields an Na-K temperature around $260^{\circ} \mathrm{C}$ (Figure 11a), although this result should be considered highly speculative because of the lack of $\mathrm{pH}$, silica, and other analytical data necessary to better assert the applicability of geothermometry calculations for this sample. An attempt to reconstruct the deep fluid composition for this sample to better constrain possible deep reservoir temperature by optimized multicomponent equilibrium geothermometry using iGeoT (Spycher et al., 2014; 2016) yields estimates between $230^{\circ} \mathrm{C}$ and $250^{\circ} \mathrm{C}$, after correcting for effects of evaporative concentration, a small loss of $\mathrm{CO}_{2}$ gas, and precipitation of calcite (Figure 11b). However, these results should be viewed with caution because of poor model constraints. A few water samples reported with less alkaline pH values between 7 and 8 exhibit low $\mathrm{Na}+\mathrm{K}$ and higher $\mathrm{Ca}$ concentrations more typical of cold/shallow groundwaters.

High voltage $(100 \mathrm{kv})$ transmission lines lie $\sim 15 \mathrm{~km}$ to the southeast near Susanville, CA. With the exception of the town of Spaulding, CA, which lies on the western side of the Eagle Lake and has a population of 178, the Eagle Lake area is sparsely populated and no land in the area is protected from development.

Figure 11. (A) Na-K-Mg geothermometry plot for Eagle Lake waters: most, if not all, samples appear unsuitable for geothermometry analyses. (b) Multicomponent equilibrium geothermometry with the least immature water (point labeled 612 in (a)), after fluid reconstruction to account for effects of evaporative concentration, $\mathrm{CO}_{2}$ exsolution, and precipitation of calcite; results of traditional geothermometers applied to the reconstructed fluid are also shown.

\subsubsection{Vya, NV}

Several favorably oriented faults of unknown age are mapped in and around the ghost town of Vya, NV, which is located $\sim 50 \mathrm{~km}$ due east of Lake City, CA. The surficial geology is characterized by Oligocene to Miocene basaltic to rhyolitic lava flows and Quaternary to Tertiary sedimentary rocks (Egger and Miller, 2011). All faulting of known age within $\sim 10 \mathrm{~km}$ of Vya is very-late Pleistocene or younger $(<15,000 \mathrm{yrs})$ suggesting of active tectonism in the Vya area. Strain rates are low and no significant seismicity has been recorded since 1970. A relatively low heat flow of $78 \mathrm{~mW} / \mathrm{m}^{2}$ is reported in a well $\sim 2 \mathrm{~km}$ east of Vya. A geothermal gradient of $702^{\circ} \mathrm{C} / \mathrm{km}$ has been reported at Vya. This suggests convective fluid flow, however no depth information is reported for this well, so we view this geothermal gradient as somewhat suspect.

Only four water analyses with sufficient information to apply traditional geothermometers are available from springs near Vya. Geothermometry suggest $\mathrm{Na} / \mathrm{K}$ temperatures as high as $330^{\circ} \mathrm{C}$, however these temperatures are not in good agreement with the $\mathrm{SiO}_{2}$ and $\mathrm{K} / \mathrm{Mg}$ geothermometers, which yield much lower temperatures (up to $\sim 116^{\circ} \mathrm{C}$ and $66^{\circ} \mathrm{C}$, respectively). Also, the measured temperatures of these fluids at the surface are only $\sim 22^{\circ} \mathrm{C}$. Therefore, there is a large uncertainty about the actual temperature of thermal fluids at depth in this area. When plotted on a ternary $\mathrm{Na} / \mathrm{K} / \mathrm{Mg}$ geothermometry diagram, the four analyses are found to plot essentially on $\mathrm{Mg}$ corner and for this reason such a plot is not presented. Three of these waters are dilute (15-20 $\mathrm{mg} / \mathrm{L} \mathrm{Cl})$ and one is significantly more concentrated $(900 \mathrm{mg} / \mathrm{L} \mathrm{Cl})$ although with the lowest silica concentration of all samples. Attempts to reconstruct a possible deep fluid composition by optimized multicomponent geothermometry with iGeoT (Spycher et al., 2014; 2016) are successful (although highly uncertain) only when using the diluted samples. These computations yielded fairly focused temperatures in the $265-280^{\circ} \mathrm{C}$ range, but only after correcting for significant dilution (factor $\sim 8 \mathrm{x}$ ) and degassing. These results should be considered highly uncertain because of the strong dilution of the sample and the poor model constraints.

Land classified as a Historic/Scenic trail and National Conservation Area by the Bureau of Land Management surround Vya, however the land on which the highest temperature gradient is reported has no restrictions. A total population of 6 is listed in the census block containing the town of Vya. A high voltage power corridor lies $\sim 7 \mathrm{~km}$ east of Vya.

\subsubsection{Bonham Ranch, NV}

Bonham Ranch, NV lies $\sim 50 \mathrm{~km}$ west southwest of San Emidio. The surficial geology is characterized by Pliocene to Pleistocene basaltic lava flows (Crafford, 2010). The Bonham Ranch area contains a very high 
density of well-oriented faults, several of which are very-late Pleistocene $(15,000 \mathrm{yrs})$ or younger. Strain rates are among the highest in the study area, and scattered seismicity has been recorded since 1970. Two different right step-overs in very-late Pleistocene ( $>15,000$ yrs), late Pleistocene (>130,000 yrs), and early Pleistocene $(>1.6 \mathrm{Ma})$ faults form favorable structural settings for geothermal fluid upflow. Temperature gradients as high as $336^{\circ} \mathrm{C} / \mathrm{km}$ in wells as deep as $\sim 70 \mathrm{~m}$ are reported. Heat flow has not been calculated, as these are likely convective rather than conductive gradients.

Both springs and artesian wells with measured temperatures as high as $50^{\circ} \mathrm{C}$ are found in this area. Traditional $\mathrm{Na}-\mathrm{K}-\mathrm{Mg}$ geothermometry using available analyses of these waters (Figure 12a) suggest deep temperatures between $\sim 140^{\circ}$ and $200^{\circ} \mathrm{C}$, although the higher estimate (point 6913 on Figure 12a) is likely unreliable because this sample exhibits a salinity about 3-4 times higher than at other locations, and about 100 times higher than another sample at the same location, however with a similar low silica concentration $\left(\mathrm{T}_{\text {quartz }}\right.$ $\sim 80^{\circ} \mathrm{C}$ ). This suggests either erroneous data or evaporative concentration with silica re-equilibration. Shevenell and Coolbaugh (2011) applied an approach combining geothermometers and enthalpy data to estimate deep temperatures at several thermal springs in Nevada and estimated deep temperatures around $165^{\circ} \mathrm{C}$ at Bonham Ranch, which is within the range with our $\mathrm{Na}-\mathrm{K}-\mathrm{Mg}$ geothermometry and multicomponent geothermometry results (Figure 12). Multicomponent geothermometry analyses using iGeoT (Spycher et al., 2014; 2016) using the samples with the highest collection temperatures $\left(37^{\circ} \mathrm{C}\right.$ and $49^{\circ} \mathrm{C}$, points 5622 and 5624 on Figure 12a) yield deep temperatures of 154 and $126^{\circ} \mathrm{C}$, respectively (Figure 12b). An initial attempt to reconstitute the high salinity sample 6913 by optimized multicomponent geothermometry, in order to account for evaporative concentration and silica re-equilibration, yields a temperature of $166^{\circ} \mathrm{C}$.

The Bonham Ranch area does not consist of land that is protected from development, although it is adjacent to a Bureau of Land Management Wilderness Study Area to the west. The area is very sparsely populated and lies $\sim 25 \mathrm{~km}$ from high voltage transmission corridors to the northwest, southwest, and east.

Figure 12. (a) Na-K-Mg geothermometry plot for the Bonham Ranch thermal waters. Labeled points show samples from wells with highest fluid temperatures (5622 and 5624), and one cold spring sample (6913) exhibiting higher salinity than the rest of the samples. (b) Multicomponent equilibrium geothermometry with two of the more mature waters (point labeled 5622 and 5624 in (a)), after fluid reconstruction to account for effects of dilution, some $\mathrm{CO}_{2}$ exsolution, and precipitation of calcite; results of traditional geothermometers applied to the reconstructed fluid are also shown.

\subsubsection{New Pine Creek, CA and OR}

New Pine Creek straddles the border between California and Oregon near the northeastern end of Goose Lake. The area is characterized by Miocene basaltic to rhyolitic lava flows and intrusive rocks, and Quaternary sedimentary rocks (Gay and Aune, 1958; Walker, 1963). A relatively high density of well-oriented faults and a step-over along the range-front fault system, which is younger than late Pleistocene $(<130,000 \mathrm{yrs})$, result in the relatively high permeability favorability at New Pine Creek. Strain rates are moderate, relative to the Modoc study area as a whole, although a seismicity swarm peaking between 2004-2007 containing 450 events, including events of $M=4.4$ on June 30, 2004 and $M=4.2$ on July 22, 2004, indicates active deformation. A total population of 255 is listed in the census blocks in and around New Pine Creek and a high voltage power corridor passes within $2 \mathrm{~km}$ of the town. Heat flow values of 572, 175, 97, and $91 \mathrm{~mW} / \mathrm{m}^{2}$ have been calculated in the area. No land near New Pine Creek is subject to restrictions on geothermal development.

Water temperatures as high as $77^{\circ} \mathrm{C}$ are reported in wells of unknown depth in the New Pine Creek area, clearly indicating convective hydrothermal activity in the area. 113 water analyses from wells and springs are available for this area, although most are incomplete. Reported water compositions appear to fall in two distinct groups: dilute waters with elevated $\mathrm{Ca}+\mathrm{Mg}$ relative to $\mathrm{Na}+\mathrm{K}$, representative of cold ground waters, and higher salinity, Na-Cl-dominant warmer waters. Geothermometry analyses with the warmest waters yield $\mathrm{Na} / \mathrm{K}$ temperatures up to $\sim 169^{\circ} \mathrm{C}$ (Figure 13a), although this is inconsistent with (and significantly higher than) 
temperatures estimated with other traditional geothermometers. Taking the two warmest/most concentrated of these waters (labeled points on Figure 13a), attempts were made to estimate deep mineral equilibration temperatures by optimized multicomponent geothermometry using iGeoT (Spycher et al., 2014; 2016); tentative results indicate temperatures in the 130 to $140^{\circ} \mathrm{C}$ range (Figure 13b). Elevated $\mathrm{Na} / \mathrm{K}$ geothermometer temperatures $\left(>200^{\circ} \mathrm{C}\right)$ are computed for many other waters, however only for those with incomplete analyses and/or compositions suggesting cold groundwater not suitable for traditional geothermometry.

Figure 13. (a) Na-K-Mg geothermometry plot for the New Pine Creek thermal waters. Labeled points show samples from wells with highest fluid temperatures (175 and 15090); (b) Multicomponent equilibrium geothermometry with the two labeled points in (a) (most mature waters) after fluid reconstruction to account for effects of dilution, some $\mathrm{CO}_{2}$ exsolution, and precipitation of calcite; results of traditional geothermometers applied to the reconstructed fluid are also shown.

\subsection{Play types throughout the Modoc study area}

The producing geothermal system at San Emidio serves as our training site for tectonically-hosted, or Basin and Range-type geothermal systems. San Emidio is characterized by relatively dense faulting, all of which is younger than 130,000 yrs. Faults are relatively well oriented with respect to the tectonic stress field. The geothermal system at San Emidio occupies a favorable structural setting, a $\sim 4 \mathrm{~km}$ wide left step-over in the San Emidio fault zone (Rhodes, 2011). Temperature gradients are among the highest in the Modoc study area, though no heat flow calculations are available. The maximum temperature recorded in the field to date (in well $45 \mathrm{~A}-21)$ is $161^{\circ} \mathrm{C}$, and production predominantly comes from wells with temperatures of 138 to $149^{\circ} \mathrm{C}$ (Teplow and Warren, 2015). Na/K geothermometry with samples from thermal springs and a deep well at San Emidio yield elevated temperatures up to $219^{\circ} \mathrm{C}$ (Figure 14), however these temperatures appear overestimated as a result of evaporative processes and/or interaction of reservoir fluids with evaporitic brine/minerals. Optimized multicomponent geothermometry computations with iGeoT (Spycher et al., 2014; 2016) yield lower temperatures $\left(160^{\circ}-170^{\circ} \mathrm{C}\right.$, Figure 14$)$ that are more consistent with field data, but only after correcting the composition of sampled fluids for degassing and significant evaporative concentration (by $\sim 30 \%$ ).

Figure 14. (a) Na-K-Mg geothermometry plot for San Emidio thermal waters from springs (numbered points) and a geothermal well (points labled "W"); (b) Multicomponent equilibrium geothermometry with the points labeled " 1 " and " $W$ " in (a) (sampled at 79 C and 135 C, respectively) after fluid reconstruction to account for effects of evaporative concentration, $\mathrm{CO}_{2}$ exsolution, and precipitation of calcite; results of traditional geothermometers applied to the reconstructed fluid are also shown.

The geothermal system at Medicine Lake, although shown to be a production-grade geothermal resource (Iovenitti and Hill, 1997), has not been developed because of concerns related to the protection of the culturally significant lands which it occupies. Medicine Lake serves as our training site for volcanically-hosted, or Cascade arc-type geothermal systems. Medicine Lake is characterized by limited surface faulting, though extensive surface coverage of Holocene-Pleistocene basaltic-rhyolitic lava flows obscures all but the youngest faults (Donnelly-Nolan and Nolan, 1986). Studies of core samples reveal that reservoir permeability is controlled by fractures (Clausen et al., 2006). Helium data (Rc/Ra value of 7.44 in well 87-13) support a magmatic fluid component (e.g., Kennedy and van Soest, 2007). Well data show among the highest heat flow and temperature gradients in the Modoc study area. Temperatures as high as $275^{\circ} \mathrm{C}$ at $\sim 1300 \mathrm{~m}$ depth have been recorded (e.g., Hulen and Lutz, 1999; Cumming and Mackie, 2007a; Cumming and Mackie, 2007b). 
Figure 15. Similarity of cells within the Modoc study area to the training sites at Medicine Lake (left side) and San Emidio (right side).

Similarity to San Emidio and Medicine Lake is calculated for each cell based on the difference in data values between the training sites and each cell. The resultant 'Difference from San Emidio' and 'Difference from Medicine Lake' maps (Figure 15), indicate the expected extent of the tectonically-hosted (San Emidio-like) and volcanically-hosted (Medicine Lake-like) geothermal systems throughout the study area.

Volcanically hosted geothermal systems are expected primarily on the western side of the Modoc study area, their distribution controlled by the occurrence of young lava flows and elevated subsurface temperatures. They are expected in highest density to the east of Medicine Lake near the towns of Canby and Alturas, CA, as well as to the east of the Lassen KGRA, near Eagle Lake, CA, and extending as far east as Susanville, CA (Figure $15)$.

San Emidio-like, tectonically hosted geothermal systems are expected throughout the study area, primarily controlled by densely spaced, young, well-oriented faults, and favorable structural settings, along with elevated subsurface temperatures. They are expected to be most prevalent throughout the Honey Lake Basin southeast of Susanville, CA and in the Smoke Creek Desert to the west of San Emidio. San Emidio-like geothermal systems are also expected along north-northwest-striking faults south of the town of Alturas, CA, in Surprise Valley, CA, and near Lakeview, OR (Figure 15).

The yet-to-be-developed relatively favorable, relatively low-risk geothermal prospects defined in this study (Figures 8 and 9) at Bonham Ranch, NV, Boulder Flat, NV, and New Pine Creek, have similar characteristics to San Emidio, namely many young and well-oriented faults and relatively high measured or calculated temperatures. None of these areas have characteristics that are particularly similar to Medicine Lake and are therefore classified as Basin and Range play-type geothermal prospects. The Eagle Lake, CA area shows characteristics of both San Emidio and Medicine Lake, namely young lava flows, relatively high temperatures, and many young and well-oriented faults. We therefore classify Eagle Lake as a transitional play-type, with similarities to both Basin and Range-type and Cascade Arc-type geothermal systems. The Vya, NV area does not appear to be particularly similar to either Medicine Lake or San Emidio, though the cells with the highest geothermal favorability near Vya, NV are more like San Emidio than they are like Medicine Lake.

\section{CONCLUSIONS}

Geothermal favorability and exploration risk throughout the Modoc plateau and the surrounding region in California, Oregon, and Nevada, are calculated based on play-fairway analysis. Six proxies for heat and seven proxies for permeability are synthesized using fuzzy logic, allowing for definition of highly favorable and low risk geothermal prospects. The results independently identify many of the already known and developed geothermal systems in Modoc area. This suggests that our methods are viable for locating geothermal resources, and may have broad application in other areas in the United States and internationally. In addition to identifying the already known geothermal systems throughout the Modoc area we have identified five relatively unknown and undeveloped geothermal prospects. These are at Bonham Ranch, NV, New Pine Creek, OR and CA, Eagle Lake, CA, Boulder Flat, NV, and Vya, NV. The proximity of Boulder Flat, New Pine, Creek, and Vya to existing high voltage transmission may facilitate development of these prospects for development, though significant exploration is needed to further characterize the systems. The towns near Eagle Lake and New Pine Creek make these prospects viable for district heating and other municipal direct uses. In addition to these new geothermal prospects, our analysis suggests that some known and developed resources in the Modoc area may be underutilized. The known resources at Lakeview, OR, and Lake City, CA in particular exhibit high heat flow, high measured temperatures, and good evidence for permeability, resulting in high favorability and moderate risk in our analysis (Figures 8 and 9), yet have only been exploited for direct use applications. Additional research and exploration are required to fully evaluate both the newly identified prospects at Boulder Flat, Vya, New Pine Creek, Eagle Lake, and Bonham Ranch, and the potentially underutilized geothermal systems at Lakeview, Crump Geyser, and in Surprise Valley for geothermal development. 


\section{ACKNOWLEDGMENTS}

We wish to thank Colin Williams and Jacob DeAngelo (USGS) for sharing their heat flow and well temperature data for our study. We also thank Ian Warren (US Geothermal) for providing us with detailed information on the San Emidio geothermal field, and Joe Moore (U. Utah) for sharing copies of well logs from San Emidio. This work is supported by U.S. Department of Energy Award EE-0006734 to UC Davis and funding by the Assistant Secretary for Energy Efficiency and Renewable Energy, Geothermal Technologies Office, of the U.S. Department of Energy under the U.S. Department of Energy Contract No. DE-AC0205CH11231 with Lawrence Berkeley National Laboratory. This paper benefited greatly from reviews by Jacob DeAngelo, Brent Ritzinger, and an anonymous reviewer.

\section{REFERENCES}

Aki, K., and Richards, P.G., 2002, Quantitative Seismology: Theory and Methods: University Science Books, New York.

Anderson, E.M., 1905, The Dynamics of Faulting: Transactions of the Edinburgh Geologic Society, v. 8, p. $387-402$.

Baker, R.A., Gehman, H.M., James, W.R., and White, D.A., 1986, Geologic Field Number and Size Assessment of Oil and Gas Plays, in Rice, D.D. ed., Oil and Gas Assessment, Methods and Applications: AAPG studies in Geology, p. 25-31.

Barker, B., Kennedy, B.M., Hoversten, M., Soest, M.C. Van, Williams, K., and Way, D., 2005, Geothermal Exploration at Fort Bidwell, CA: Proceedings, Thirtieth Workshop on Geothermal Reservoir Engineering, Stanford University, p. 5.

Barton, C.A., Hickman, S.H., Morin, R., Zoback, M.D., and Benoit, D., 1998, Reservoir-scale Fracture Permeability in the Dixie Valley, Nevada, Geothermal Field: Proceedings, Society of Petroleum Engineers Annual Meeting, , no. Paper No. 47371, p. 315-322, doi: 10.2523/47371-MS.

Barton, C.A., Zoback, M.D., and Moos, D., 1995, Fluid flow Along Potentially Active Faults in Crystalline Rock: Geology, v. 23, no. 8, p. 23-27, doi: 10.1130/0091-7613(1995)023<0683.

Battocletti, L., 2006, Measuring the Economic, Environmental, and Social Benefits of Nine Geothermal Heating System and Power Generation Projects: Geothermal Resources Council Transactions, v. 30, p. 1007-1011.

Blackwell, D.D., Steele, J.L., Kelley, S., and Korosec, M.A., 1990, Heat Flow in the State of Washington and Thermal Conditions in the Cascade Range: Journal of Geophysical Research, v. 95, no. B12, p. 19,419$495,516$.

Blackwell, D.D., Wisian, K.W., Benoit, W.R., and Gollan, B., 1999, The Dixie Valley Geothermal System, a "Typical" Basin and Range Geothermal System, From Thermal and Gravity Data: Geothermal Resources Council Transactions, v. 23, p. 525-531.

Blake, K., and Davatzes, N.C., 2012, Borehole Image Log and Statistical Analysis of FOH-3D, Fallon Naval Air Station, NV, in Proceedings, Thirty-Seventh Workshop on Geothermal Reservoir Engineering, Stanford University, p. 1054-1067.

Blake, K., and Davatzes, N.C., 2011, Crustal Stress Heterogeneity in the Vicinity of Coso Geothermal Field, CA, in Proceedings, Thirty-Fifth Workshop on Geothermal Reservoir Engineering, Stanford University, p. 914-924.

Bliss, J.D., and Rapport, A., 1983, Geotherm: the U.S. Geological Survey Geothermal Information System: Computers \& Geosciences, v. 9, no. 1, p. 35-39, doi: doi: 10.1016/0098-3004(83)90034-1.

Boyd, T., Sifford, A., and Lund, J.W., 2015, The United States of America Country Update 2015, in 
Proceedings of the World Geothermal Congress, p. 12.

Burkhardt, H.E., Brook, C.A., and Smith, F.W., 1980, Selected Administrative, Land, and Resource Data for Known Geothermal Resources Areas in Arizona, California, Idaho, Nevada, Oregon, and Washington: US Geological Survey Open-File Report 80-1290, p. 29.

Cantwell, C., and Fowler, A., 2014, Fluid Geochemistry of the Surprise Valley Geothermal System, in Proceedings, Thirty-Ninth Workshop on Geothermal Reservoir Engineering, Stanford University, p. 13.

Clausen, S., Nemcok, M., Moore, J., Hulen, J., and Bartley, J., 2006, Mapping Fractures in the Medicine Lake Geothermal System: Geothermal Resources Council Transactions, v. 30, p. 383-386.

Clawson, R.F., Gibson, L.R., and Luzzadder Beach, S., 1986, Surprise Valley Ground Water Basin Water Quality Study: California Department of Water Resources Report, p. 188.

Colie, E.M., 2003, Strike-Slip Motion on the Northern Continuation of the Late Tertiary to Quaternary Honey Lake fault zone at Eagle Lake, Lassen County, northeastern California [M.S. Thesis]: University of California, Davis: 90 p.

Costa, K.C., 2008, Geomicrobiological Changes in Two Ephemeral Desert Playa Lakes in the Western United States: Geomicrobiology Journal, v. 25, no. 5, p. 250-259, doi: 10.1080/01490450802153033.

Crafford, A.E.J., 2010, Geologic Terrane Map of Nevada 1:500,000 scale: Nevada Bureau of Mines and Geology Open File Report 10-4.

Cumming, W., and Mackie, R., 2007a, 3D MT Resistivity Imaging for Geothermal Resource Assessment and Environmental Mitigation at the Glass Mountain KGRA, California: Geothermal Resources Council Transactions, v. 31, no. March, p. 331-334.

Cumming, W., and Mackie, R., 2007b, MT Survey for Resource Assessment and Environmental Mitigation at the Glass Mountain KGRA California Energy Commission, Energy Research and Development Division, Report CEC-500-2013-063, p. 104.

Curewitz, D., and Karson, J.A., 1997, Structural Settings of Hydrothermal Outflow: Fracture Permeability Maintained by Fault Propagation and Interaction: Journal of Volcanology and Geothermal Research, v. 79, no. 3-4, p. 149-168, doi: 10.1016/S0377-0273(97)00027-9.

Davatzes, N.C., and Hickman, S.H., 2006, Stress and Faulting in the Coso Geothermal Field: Update and Recent Results from the East Flank and Coso Wash, in Proceedings, Thirty-First Workshop on Geothermal Reservoir Engineering, Stanford University, p. 24-35.

Donnelly-Nolan, J.M., and Nolan, K.M., 1986, Catastrophic Flooding and Eruption of Ash-Flow Tuff at Medicine Lake Volcano, California: Geology, v. 14, no. 10, p. 875-878.

Doust, H., 2010, The Exploration Play: What do We Mean by it? AAPG Bulletin, v. 94, no. 11, p. 1657-1672, doi: 10.1306/06301009168.

Duffield, W.A., Bacon, C.R., and Dalrymple, G.B., 1980, Late Cenozoic Volcanism, Geochronology, and Structure of the Coso Range, Inyo County, California: Journal of Geophysical Research, v. 85, no. B5, p. 2381, doi: 10.1029/JB085iB05p02381.

Duffield, W.A., and Fournier, R.O., 1974, Reconnaissance Study of the Geothermal Resources of Modoc County, California: U.S. Geological Survey Open-File Report 74-1024, p. 21.

Egger, A.E., Glen, J.M.G., and McPhee, D.K., 2014, Structural Controls on Geothermal Circulation in Surprise Valley, California: A Re-evaluation of the Lake City fault zone: Geological Society of America Bulletin, v. 126, no. 3-4, p. 523-531, doi: 10.1130/B30785.1. 
Egger, A.E., and Miller, E.L., 2011, Evolution of the Northwestern Margin of the Basin and Range: The Geology and Extensional History of the Warner Range and Environs, northeastern California: Geosphere, v. 7, no. 3, p. 756-773, doi: 10.1130/GES00620.1.

Eliot Allen \& Associates, and Geo-Mat Inc., 1986, Assessment of Geothermal Resources in Modoc County, California: California Energy Commission Report, p. 124.

Eugster, H.P., and Hardie, L.A., 1978, Saline Lakes, in Lakes: Chemistry, Geology, Physics, Springer New York, New York, NY, p. 237-293.

Faulds, J.E., Coolbaugh, M.F., Benoit, W.R., Oppliger, G.L., Perkins, M., Moeck, I., and Drakos, P.S., 2010, Structural Controls of Geothermal Activity in the Northern Hot Springs Mountains, Western Nevada: The Tale of Three Geothermal Systems (Brady's, Desert Peak, and Desert Queen): Geothermal Resources Council Transactions, v. 34, p. 675-684.

Faulds, J.E., Coolbaugh, M.F., Vice, G.S., and Edwards, M.L., 2006, Characterizing Structural Controls of Geothermal Fields in the Northwestern Great Basin: A Progress Report: Geothermal Resources Council Transactions, v. 30, p. 69-76.

Faulds, J.E., and Henry, C.D., 2008, Tectonic Influences on the Spatial and Temporal Evolution of the Walker Lane: An Incipient Transform Fault Along the Evolving Pacific - North American Plate Boundary, in Spencer, J.E. and Titley, S.R. eds., Ores and Orogenesis: Circum-Pacific tectonics, geologic evolution and ore deposits, Geological Society of Arizona Digest 22, p. 437-470.

Faulds, J.E., Henry, C.D., and Hinz, N.H., 2005, Kinematics of the northern Walker Lane: An incipient Transform Fault Along the Pacific-North American Plate Boundary: Geology, v. 33, no. 6, p. 505-508, doi: 10.1130/G21274.1.

Faulds, J.E., Hinz, N.H., Coolbaugh, M.F., Cashman, P.H., Kratt, C., Dering, G.M., Edwards, J., Mayhew, B., and Mclachlan, H., 2011, Assessment of Favorable Structural Settings of Geothermal Systems in the Great Basin, Western USA: Geothermal Resources Council Transactions, v. 35, p. 777-784.

Faulds, J.E., Hinz, N., Kreemer, C., and Coolbaugh, M.F., 2012, Regional Patterns of Geothermal Activity in the Great Basin Region, Western USA: Correlation With Strain Rates Distribution of Geothermal Fields: Geothermal Resources Council Transactions, v. 36, p. 897-902.

Ferrill, D.A., Winterle, J., Wittmeyer, G., Sims, D., Colton, S., Armstrong, A., Horowitz, A.S., Meyers, W.B., and Simons, F.F., 1999, Stressed Rock Strains Groundwater at Yucca Mountain , Nevada: GSA Today, v. 9 , no. 5, p. 2-9.

Fournier, R.O., and Potter II, R.W., 1982, A Revised and Expanded Slica (Quartz) GeOthermometer: Geothermal Resources Council Bulletin, v. 11, p. 3-12.

Fowler, A., Cantwell, C., Spycher, N., Siler, D.L., Dobson, P., Kennedy, B.M., and Zierenberg, R.A., 2015, Integrated Geochemical Investigations of Surprise Valley Thermal Springs and Cold Well Waters, in Proceedings, Fortieth Workshop on Geothermal Reservoir Engineering, Stanford University, p. 9.

Garchar, L., Badgett, A., Neito, A., Young, K., Hass, E., and Weathers, M., 2016, Geothermal Play Fairway Analysis: Phase I Summary, in Proceedings, Forty-first Workshop on Geothermal Reservoir Engineering, Stanford University, p. 6.

Garrels, R.M., and Mackenzie, F.T., 1967, Origin of the Chemical Compositions of Some Springs and Lakes, in Gould, R.F. ed., Equilibrium Concepts in Natural Water Systems: Advances in Chemistry, p. 222-242.

Gay, T.E., and Aune, Q.A., 1958, Geologic Map of California, Olaf Jennings Edition, Alturas Sheet 1:250,000 scale: California Division of Mines and Geology. 
Geothermal Energy Association, 2015, Annual U S \& Global Geothermal Power Production Report, p. 21.

Giggenbach, W.F., 1988, Geothermal Solute Equilibria. Derivation of Na-K-Mg-Ca Geoindicators: Geochimica et Cosmochimica Acta, v. 52, no. 12, p. 2749-2765, doi: 10.1016/0016-7037(88)90143-3.

Godwin, L.H., Haigler, L.B., Rioux, R.L., White, D.E., Muffler, L.J., and Wayland, R.G., 1971, Classification of Public Lands Valuable for Geothermal Steam and Associated Geothermal Resources: US Geological Survey Circular 647, p. 18.

Greene, R.C., Walker, G.W., and Corcoran, R., 1972, Geologic Map of The Burns Quadrangle, Oregon: 1:250,000 scale: US Geological Survey Miscellaneous Geologic Investigations Map I-680.

Heidbach, O., Tingay, M., Barth, A., Reinecker, J., Kurfeß, D., and Müller, B., 2008, The World Stress Database Release 2008.

Hickman, S.H., and Davatzes, N.C., 2010, In-situ Stress and Fracture Characterization for Planning of an EGS Stimulation in the Desert Peak Geothermal Field, Nevada, in Proceedings, Thirty-Fifth Workshop on Geothermal Reservoir Engineering, Stanford University, p. 13.

Hickman, S.H., Zoback, M.D., Barton, C.A., Benoit, W.R., Svitek, J., and Summers, R., 2000, Stress and Permeability Heterogeneity within the Dixie Valley Geothermal Reservoir: Recent Results from Well 825, in Proceedings, Twenty-Fifth Workshop on Geothermal Reservoir Engineering, Stanford University, p. 256-265.

Hickman, S., Zoback, M.D., and Benoit, W.R., 1998, Tectonic Controls on Reservoir Permeability in the Dixie Valley, Nevada, Geothermal Field, in Proceedings, Twenty-Third Workshop on Geothermal Reservoir Engineering, Stanford University, p. 291-298.

Hinz, N.H., Faulds, J.E., Moeck, I.S., Bell, J.W., and Oldow, J.S., 2010, Structural Controls of Three Blind Geothermal Resources at the Hawthorne Ammunition Depot, West-Central Nevada: Geothermal Resources Council Transactions, v. 34, p. 785-790.

Hinz, N.H., Faulds, J.E., and Oppliger, G.L., 2008, Structural Controls of Lee Hot Springs, Southern Churchill County, Western Nevada: A Small Pull-Apart in the Dextral Shear Zone of the Walker Lane: Geothermal Resources Council Transactions, v. 32, p. 285-289.

Hinz, N.H., Faulds, J.E., and Stroup, C., 2011, Stratigraphic and Structural Framework of the Reese River Geothermal Area, Lander County, Nevada: A New Conceptual Structural Model: Geothermal Resources Council Transactions, v. 35, p. 827-832.

Hulen, J.B., and Lutz, S.J., 1999, Altered Volcanic Rocks as Hydrologic Seals on the Geothermal System of the Medicine Lake Volcano: Geothermal Resources Council Bulletin, v. Sept./Oct., p. 217-222.

Ingebritsen, S.E., Galloway, D.L., Colvard, E.M., Sorey, M.L., and Mariner, R.H., 2001, Time-Variation of Hydrothermal Discharge at Selected Sites in the western United States: Implications for Monitoring: Journal of Volcanology and Geothermal Research, v. 111, no. 1-4, p. 1-23, doi: 10.1016/S03770273(01)00207-4.

Ingebritsen, S.E., Sherrod, D.R., and Mariner, R.H., 1989, Heat flow and Hydrothermal Circulation in the Cascade Range, north-central Oregon: Science, v. 243, no. 4897, p. 1458-1462, doi: 10.1126/science.243.4897.1458.

Iovenitti, J., and Hill, D.G., 1997, Baseline Hydrogeology Evaluation Report for Telephone Flat Geothermal Project, Medicine Lake, California: Emeryville, California, Weiss Associates, Report Prepared for CalEnergy Corporation, p. 34.

Ito, T., and Zoback, M.D., 2000, Fracture Permeability and in Situ Stress to 7 km Depth in the KTB Scientific 
Kennedy, B.M., and van Soest, M.C., 2007, Flow of Mantle Fluids Through the Ductile Lower Crust: Helium Isotope Trends: Science, v. 318, p. 1433-1436, doi: 10.1126/science.1147537.

Kreemer, C., Blewitt, G., and Hammond, W.C., 2009, Geodetic Constraints on Contemporary Deformation in the northern Walker Lane: 2. Velocity and Strain Rate Tensor Analysis, in Oldow, J.S. and Cashman, P.H. eds., Late Cenozoic Structure and Evolution of the Great Basin Sierra Nevada Transition, Geological Society of America Special Paper 447, p. 17-31.

Kreemer, C., Hammond, W.C., Blewitt, G., Holland, A.A., and Bennett, R.A., 2012, A Geodetic Strain Rate Model for the Pacific - North American Plate Boundary, Western United States: Nevada Bureau of Mines and Geology, Reno, Nevada.

Livingstone, D.A., 1963, Chemical Composition of Rivers and Lakes, Chapter G, in Fleischer, M. ed., Data of Geochemistry, p. 61.

Ludington, S.D., Moring, B.C., Miller, R.J., Stone, P.A., Bookstorm, A.A., Bedford, D.R., Evans, J.G., Haxel, G.A., Nutt, C.J., Flyn, K.S., and Hopkins, M.J., 2005, Preliminary Integrated Geologic Map Databases for the United States - western States: California, Nevada, Arizona, Washington, Oregon Idaho, and Utah 1:500,000 and 1:750,000 scale: US Geological Survey Open-File Report 2005-1305.

Lydon, P.A., Gay, T.E., and W, J.C., 1960, Geologic Map of California, Olaf Jennings Edition, Westwood Sheet 1:250,000 scale: State of California Department of Natural Resources.

Macleod, N.S., and Sherrod, D.R., 1992, Reconnaissance Geologic Map of the West Half of the Crescent $1^{\circ}$ by $2^{\circ}$ Quadrangle, Central Oregon 1:250,000 scale: US Geological Survey Miscellaneous Geological Investigations Map I-2215.

Mariner, R.H., Presser, T.S., and Evans, W.C., 1993, Geothermometry and Water-Rock Interaction in Selected Thermal Systems in the Cascade Range and Modoc Plateau, western United States: Geothermics, v. 22, no. 1 , p. $1-15$.

McNamara, D.D., Massiot, C., Lewis, B., and Wallis, I.C., 2015, Heterogeneity of Structure and Stress in the Rotokawa Geothermal Field, New Zealand: Journal of Geophysical Research: Solid Earth, v. 120, p. 1243-1262, doi: 10.1002/2014JB011480.Received.

Merrick, D., 2006a, Adventures in the Life of a Small Geothermal District Heating Project (The Little Project That Did) Part III: Geothermal Resources Council Transactions, v. 30, p. 219-224.

Merrick, D., 2009, Canby's Geothermal Laundromat: Geothermal Resources Council Transactions, v. 33, p. 589-592.

Merrick, D., 2006b, Direct-Use Geothermal in Indian Country: The Ft. Bidwell Indian Community Geothermal District Heating Project: Geothermal Resources Council Transactions, v. 30, no. 225-228.

Miller, B.M., 1982, Application of Exploration Play-Analyss Techniques to the Assessment of Convetional Petroleum Resources by the USGS: Journal of Petroleum Teconology, v. 34, p. 55-64.

Moeck, I., Hinz, N.H., Faulds, J.E., Bell, J.W., Kell-hills, A., and Louie, J., 2010, 3D Geological Mapping as a New Method in Geothermal Exploration: A Case Study from Central Nevada: Geothermal Resources Council Transactions, v. 34, p. 807-812.

Moos, D., and Ronne, J., 2010, Selecting the Optimal Logging Suite for Geothermal Reservoir Evaluation: Results from the Alum 25-29 Well, Nevada: Geothermal Resources Council Transactions, v. 34, p. 605614.

Morris, A., Ferrill, D.A., and Henderson, D.B., 1996, Slip-tendency Analysis and Fault Reactivation: Geology, 
v. 24 , no. 3 , p. $275-278$.

917

918

919

920

921

922

923

924

925

926

927

928

929

930

931

932

933

934

935

936

937

938

939

940

941

942

943

944

945

946

947

948

949

950

951

952

953

954

955

956

Nehring, N.L., and Mariner, R.H., 1979, Sulfate-Water Isotopic Equilibrium Temperatures for Thermal Springs and Wells of the Great Basin: Geothermal Resources Council Transactions, v. 3, p. 485-488.

Peiffer, L., Wanner, C., Spycher, N., Sonnenthal, E.L., Kennedy, B.M., and Iovenitti, J., 2014, Optimized Multicomponent vs. Classical Geothermometry: Insights from Modeling Studies at the Dixie Valley Geothermal Area: Geothermics, v. 51, p. 154-169, doi: 10.1016/j.geothermics.2013.12.002.

Reed, M.J., 1975, Chemistry of Thermal Water in Selected Geothermal Areas of California: California Division of Oil and Gas, Publication TR15, p. 35.

Rhodes, G.T., 2011, Structural controls of the San Emidio geothermal system, Northwestern Nevada [M.S. Thesis]: University of Nevada, Reno, 82 p.

Robertson-Tait, A., Lutz, S.J., Sheridan, J., and Morris, C.L., 2004, Selection of an Interval for Massive Hydraulic Stimulation in Well DP 23-1 Desert Peak East EGS Project, Nevada, in Proceedings, TwentyNinth Workshop on Geothermal Reservoir Engineering, Stanford University, p. 216-221.

Saucedo, G.J., and Wagner, D.L., 1992, Geologic Map of the Chico Quadrangle, California 1:250,000 scale: California Geological Survey, Regional Geologic Map No 7A.

Sherrod, D.R., and Pickthorn, L.B.G., 1992, Geologic Map of the West Half of the Klamath Falls $1^{\circ}$ by $2^{\circ}$ Quadrangle, South-Central, Oregon 1:250,000 scale: US Geological Survey, Miscellaneous Geological Investigations Map I-2182.

Shevenell, L.A., and Coolbaugh, M.F., 2011, A new Method of Evaluation of Chemical Geothermometers for Calculating Reservoir Temperatures from Thermal Springs in Nevada: Geothermal Resources Council Transactions, v. 35, p. 657-661.

Sibson, R.H., 1994, Crustal Stress, Faulting andFluid Flow, in Parnell, J. ed., Geofluids: Origin, Migration and Evolution of Fluids in Sedimentary Basins, Geological Society, London, Special Publications, p. 69-84.

Sibson, H., 1996, Structural Permeability of Fluid-Driven Fault-Fracture: Journal of Structural Geology, v. 18, no. 8, p. 1031-1042.

Siler, D.L., and Kennedy, B.M., 2016, Regional Crustal-Scale Structures as Conduits for Deep Geothermal Upflow: Geothermics, v. 59, p. 27-37, doi: 10.1016/j.geothermics.2015.10.007.

Sladek, C., Arehart, G.B., and Benoit, W.R., 2004, Geochemistry of the Lake City Geothermal System, California, USA: Geothermal Resources Council Transactions, v. 28, no. 363-368.

Spycher, N., Finsterle, S., and Dobson, P., 2016, New Developments in Mulitcomponenet Geothermometry, in Proceedings, Forty-first Workshop on Geothermal Reservoir Engineering, Stanford University, p. 9.

Spycher, N., Peiffer, L., Sonnenthal, E.L., Saldi, G., Reed, M.H., and Kennedy, B.M., 2014, Integrated Multicomponent Solute Geothermometry: Geothermics, v. 51, p. 113-123, doi: 10.1016/j.geothermics.2013.10.012.

Teplow, W.J., and Warren, I., 2015, Finding Large Aperture Fractures in Geothermal Resource Areas Using a Three-Component Long-Offset Surface Seismic Survey, PSInSAR and Kinematic Structural Analysis: Report submitted to USDOE Office of Energy Efficiency and Renewable Energy (EERE) and Geothermal Technologies Office (EE-4G) by US Geothermal Inc., p. 52.

Torgersen, T., and Jenkins, W.J., 1982, Helium Isotopes in Geothermal Systems: Iceland, The Geysers, Raft River and Steamboat Springs: Geochimica et Cosmochimica Acta, v. 46, p. 739-748.

Townend, J., and Zoback, M.D., 2000, How Faulting Keeps the Crust Strong: Geology, v. 28, no. 5, p. 399- 
958

U.S. Geological Survey, 2006, Quaternary Fault and Fold Database for the United States, accessed February 2014, from US Geological Survey website: http//earthquakes.usgs.gov/regional/qfaults/.

Walker, G.W., 1963, Reconnaissance Geologic Map of the Eastern Half of the Klamath Falls (AMS) Quadrangle, Lake and Klamath Counties, Oregon 1:250,000 scale: US Geological Survey.

Walker, G.W., Peterson, N.V., and Greene, R.C., 1967, Reconnaissance Geologic Map of the east half of the Crescent Quadrangle, Lake, Deschutes, and Crook Counties, Oregon: US Geological Suvery Miscellaneous Geologic Investigations Map I-493.

Walker, G.W., and Repenning, C.A., 1965, Reconnaissance Geologic Map of the Adel Quadrangle, Lake, Harney, and Malhuer Counties, Oregon 1:250,000 scale: US Geological Survey.

Wallis, I.C., Mcnamara, D., Rowland, J.V., and Massiot, C., 2012, The Nature of Fracture Permeability in the Basement Greywacke at Kawerau Geothermal Field, New Zealand, in Proceedings, Thirty-Seventh Workshop on Geothermal Reservoir Engineering, Stanford University, p. 232-240.

Waring, G.A., 1915, Springs in California: US Geological Survey Water-Supply Paper 338, p. 430.

Weathers, M., Hass, E., Thomas, H., Ziegenbein, M., Prisjatschew, A., Garchar, L., Segneri, B., and Emmons, S., 2015, Play Fairway Projects Initiated by the Department of Energy, in Proceedings, Fortieth Workshop on Geothermal Reservoir Engineering, Stanford University, p. 8.

Westcot, D.W., Enos, C.A., Chilcott, J.E., and Belden, K.K., 1990, Water and Sediment QuAlity Survey of Seleted Inland Saline Lakes: California Regional Water Quality Control Borad Central Valley Region, p. 19.

Williams, C.F., and DeAngelo, J., 2011, Evaluation of Approaches and Associated Uncertainties in the Estimation of Temperatures in the Upper Crust of the Western United States: Geothermal Resources Council Transactions, v. 25, p. 1599-1606.

Williams, C.F., Reed, M.J., Mariner, R.H., DeAngelo, J., and Galanis, S.P.J., 2008, Assessment of Moderateand High-Temperature Geothermal Resources of the United States US Geological Survey Fact Sheet 2008-3082, p. 4.

Wisian, K.W., and Blackwell, D.D., 2004, Numerical Modeling of Basin and Range Geothermal Systems: Geothermics, v. 33, no. 6, p. 713-741, doi: 10.1016/j.geothermics.2004.01.002.

Zhang, Y., Oldenburg, C.M., and Finsterle, S., 2009, Percolation-Theory and Fuzzy Rule-Based Probability Estimation of Fault Leakage at Geologic Carbon Sequestration Sites: Environmental Earth Sciences, v. 59, no. 7, p. 1447-1459, doi: 10.1007/s12665-009-0131-4.

Zoback, M.D., and Townend, J., 2001, Implications of Hydrostatic Pore Pressures and High Crustal Strength for the Deformation of Intraplate Lithosphere: Tectonophysics, v. 336, no. 1-4, p. 19-30, doi: 10.1016/S0040-1951(01)00091-9. 


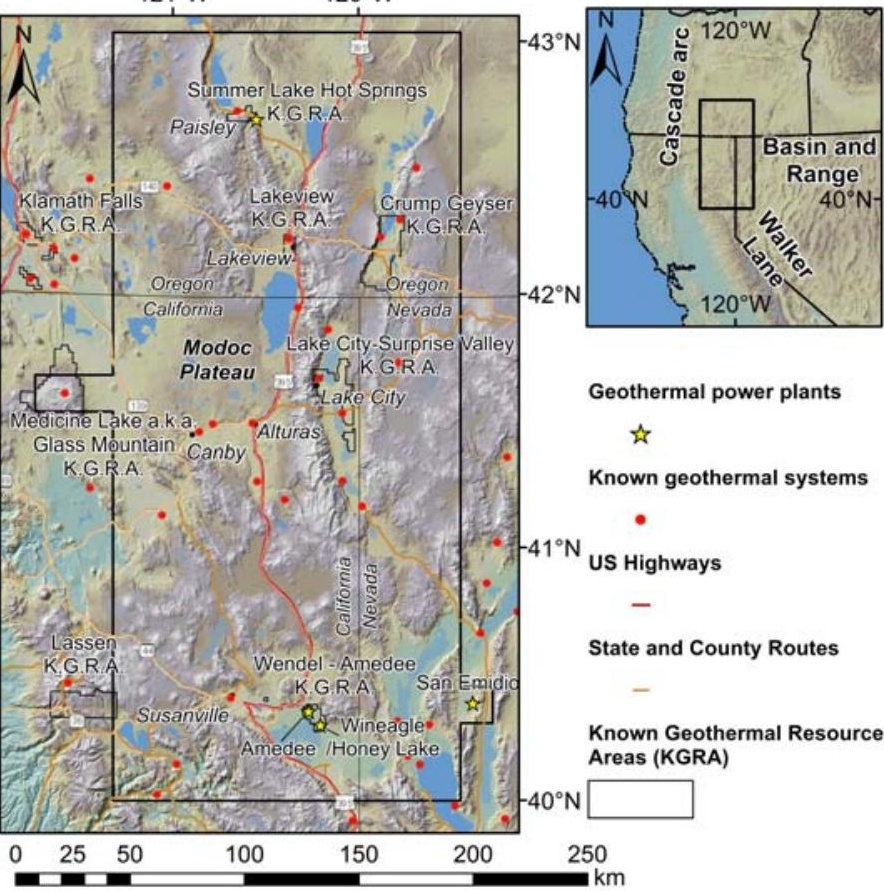




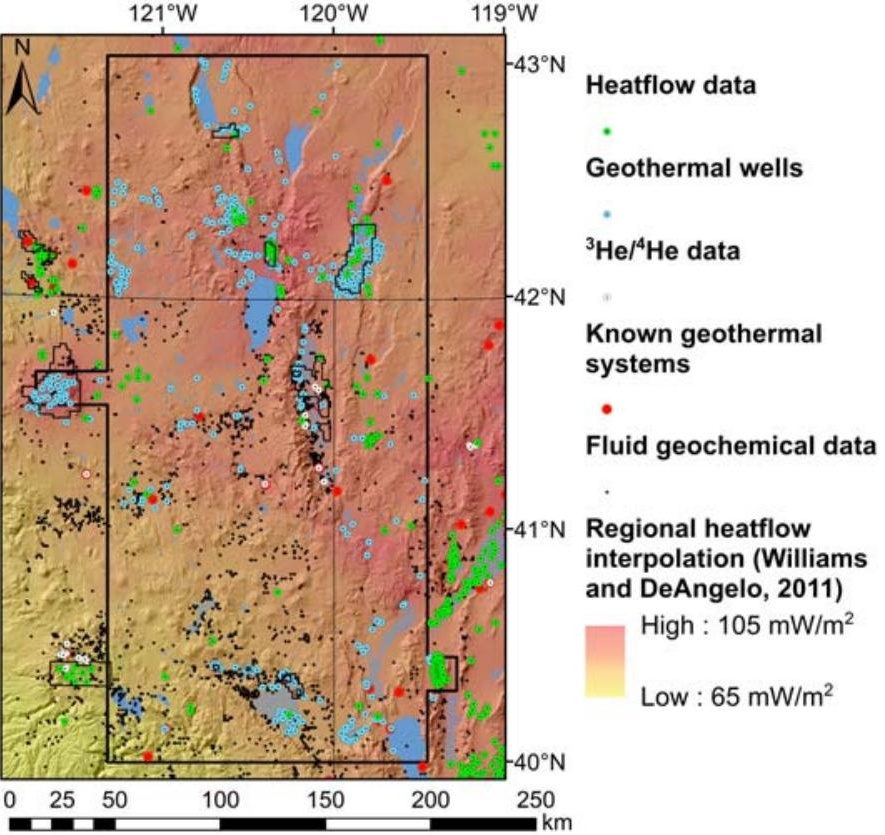




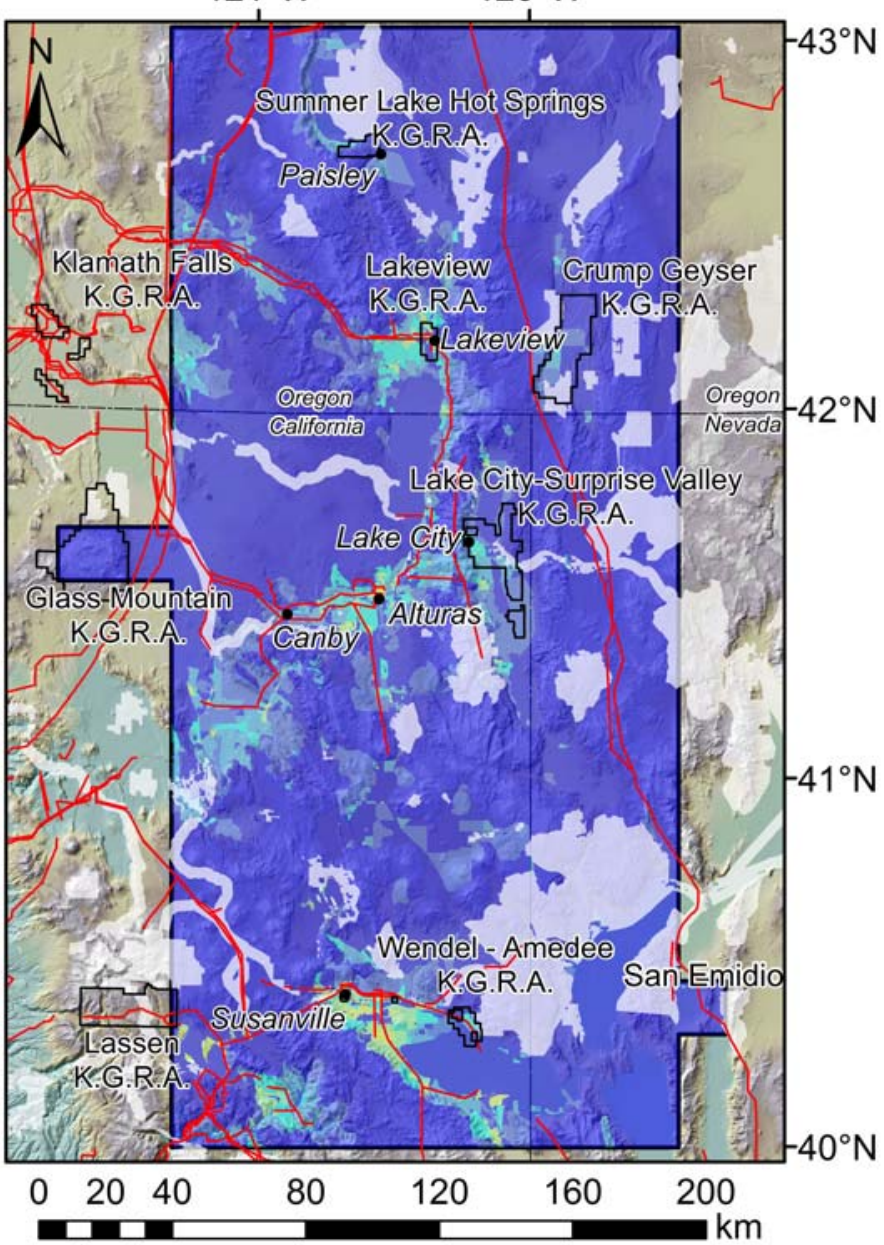

$100 \mathrm{kv}$

Transmission

\section{Population Density}

$15,000 / \mathrm{km}^{2} \quad 90 / \mathrm{km}^{2} \quad>0.1 / \mathrm{km}^{2}$ 


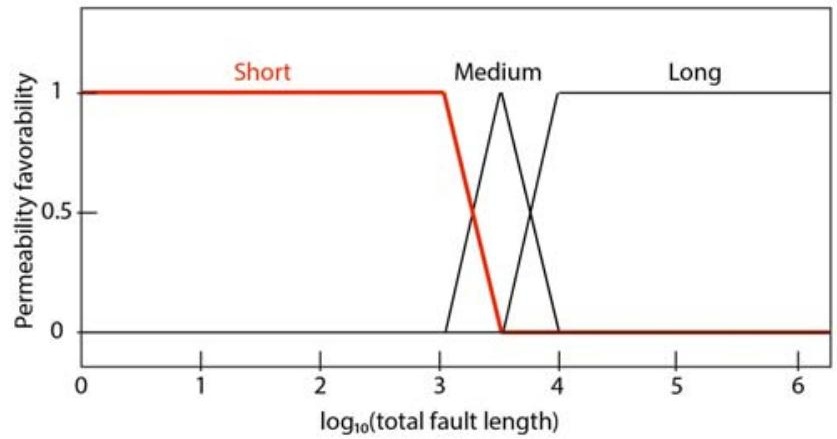




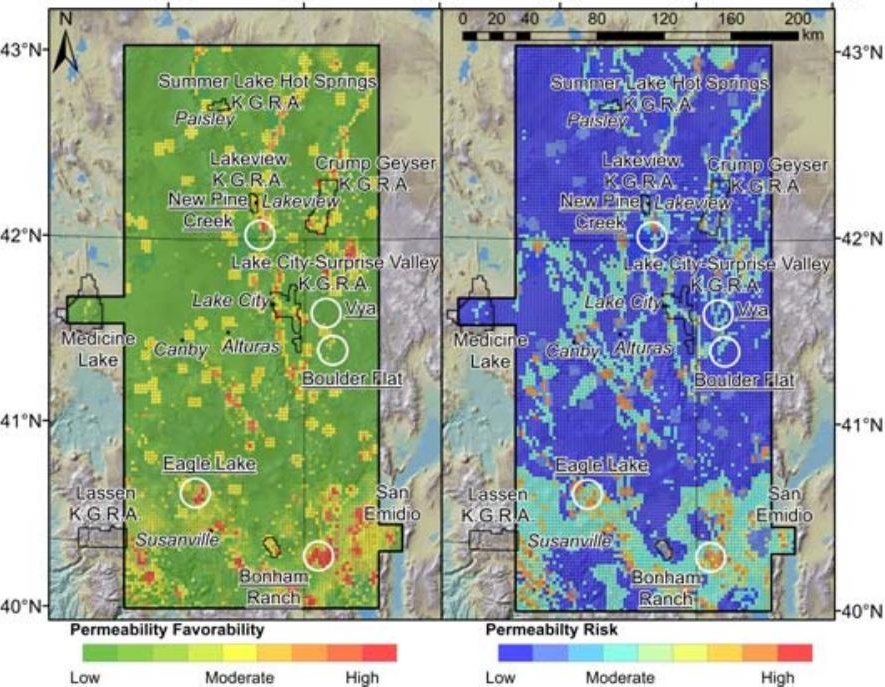




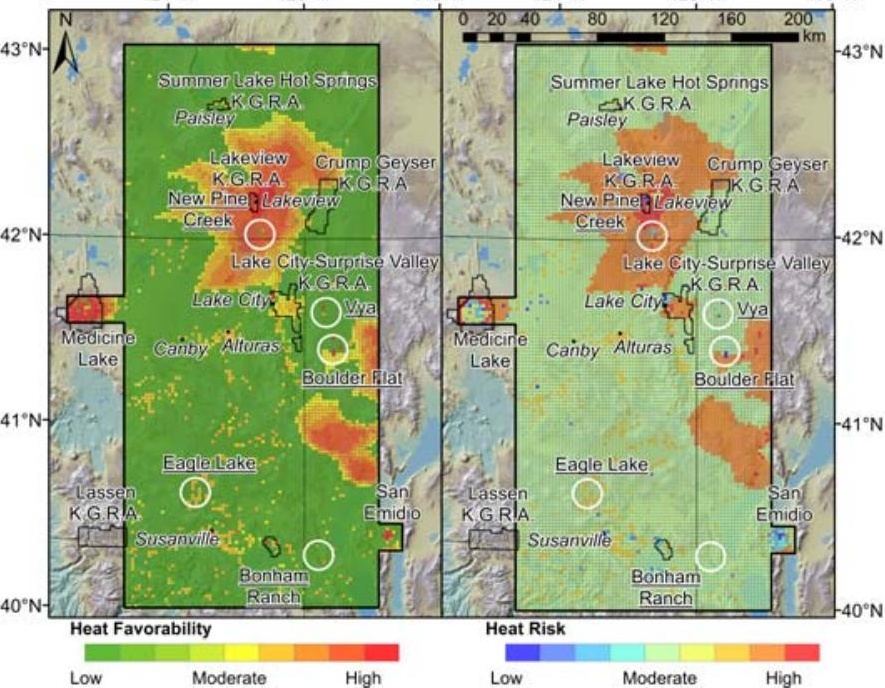




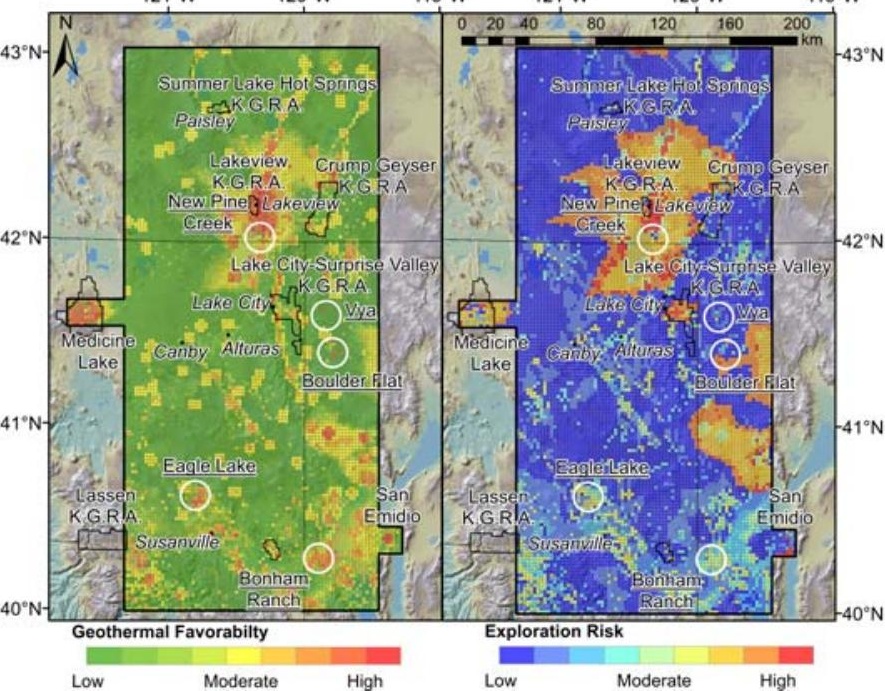


${ }^{1}$ |High Favorability/

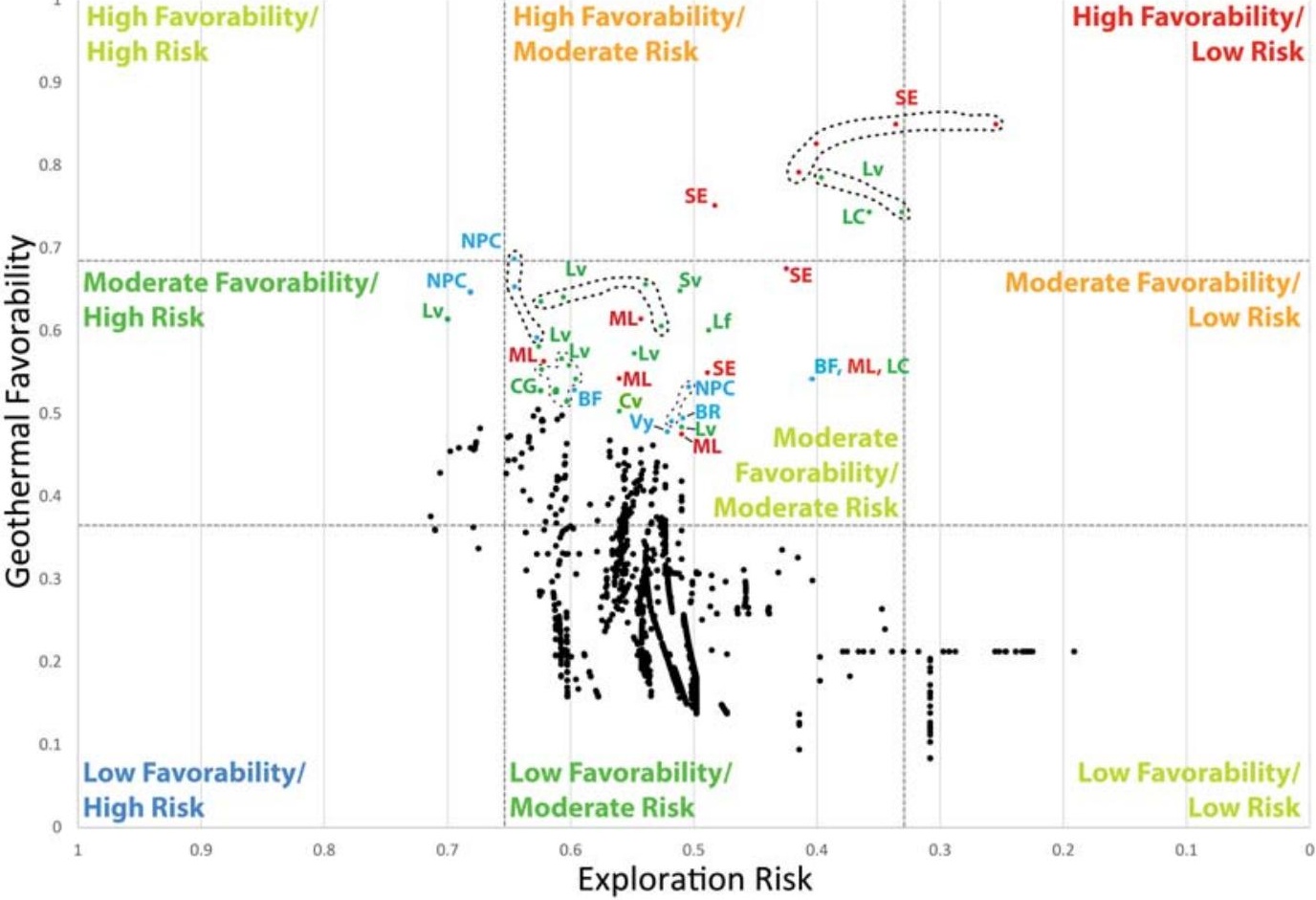




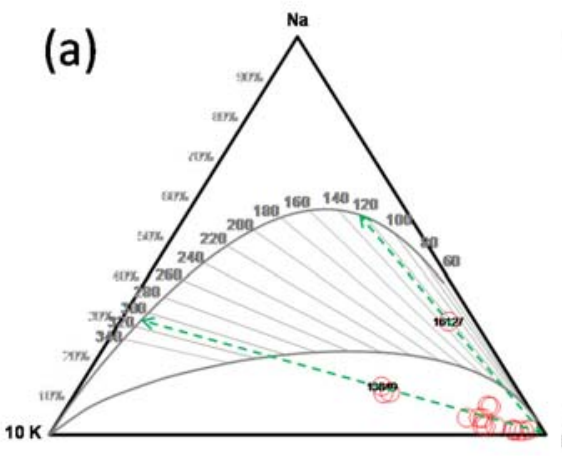

(b)

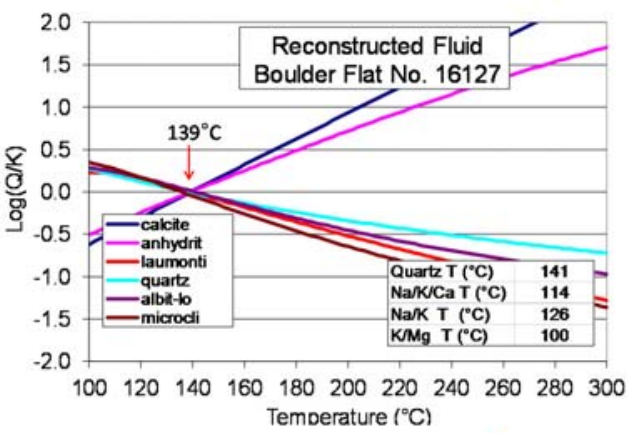

$\stackrel{1000}{M^{\wedge} 0.5}$

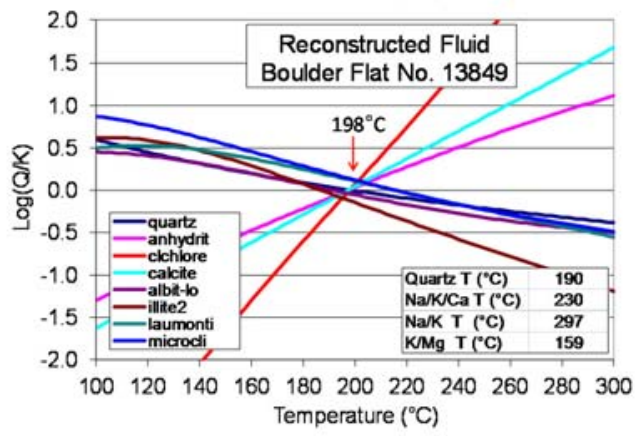



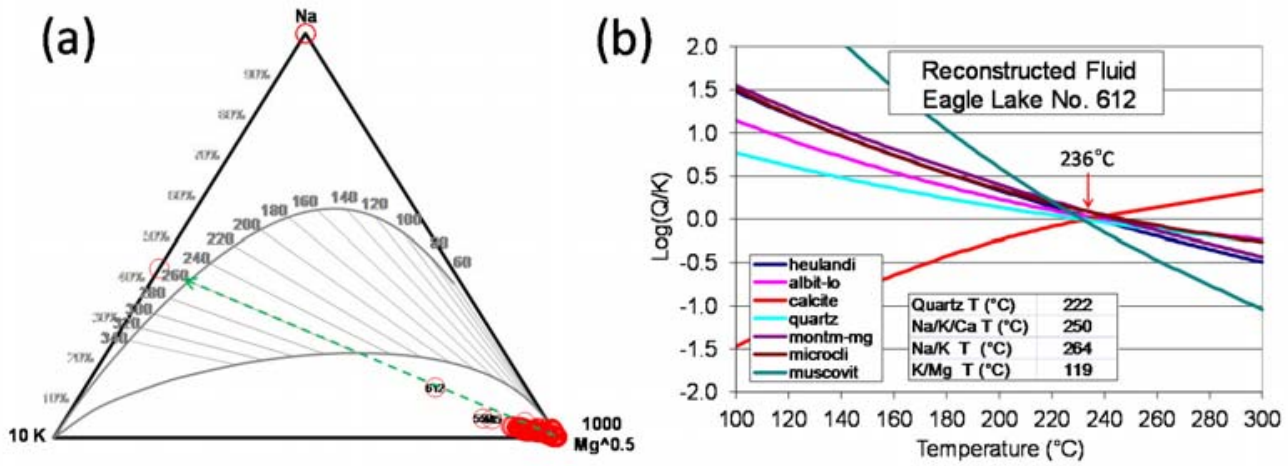

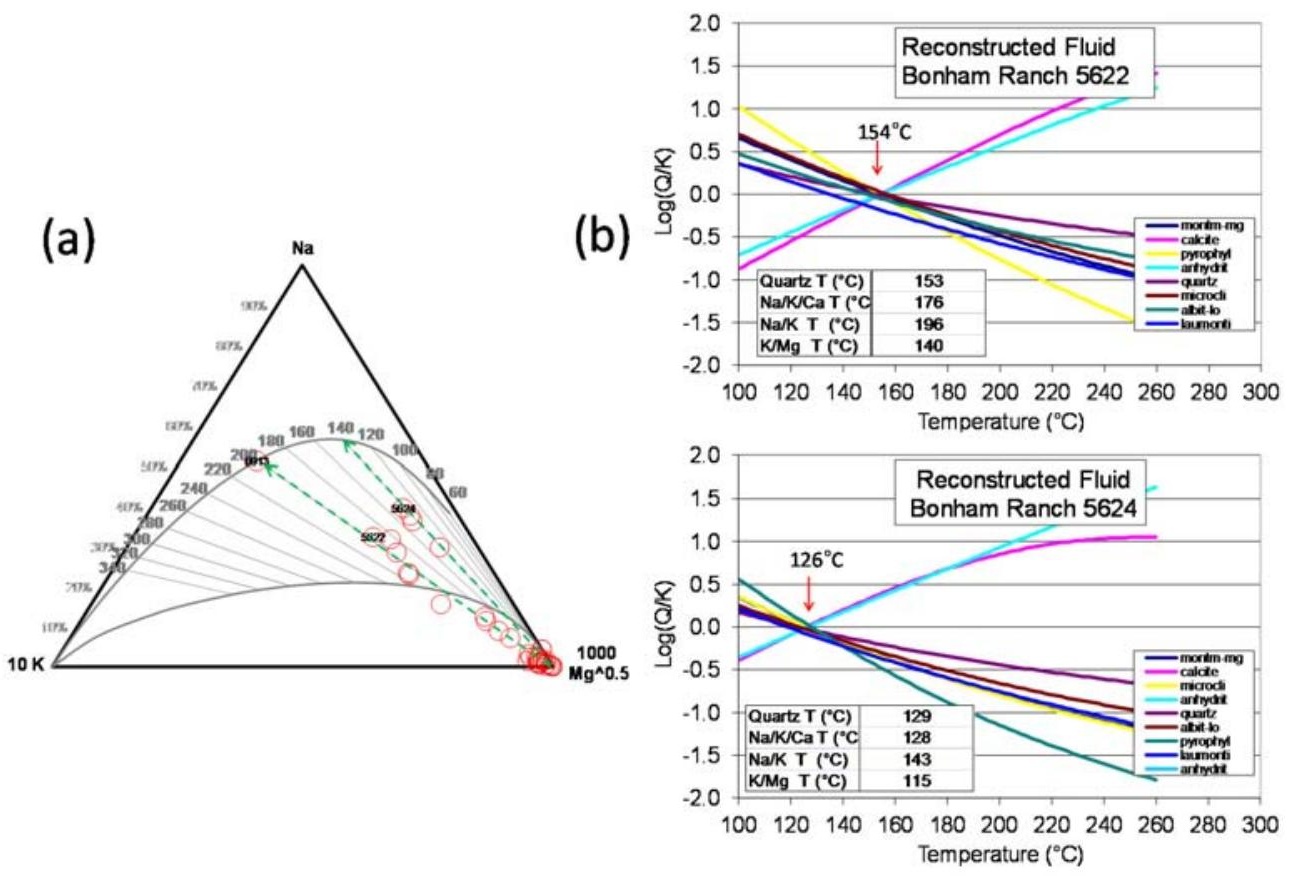


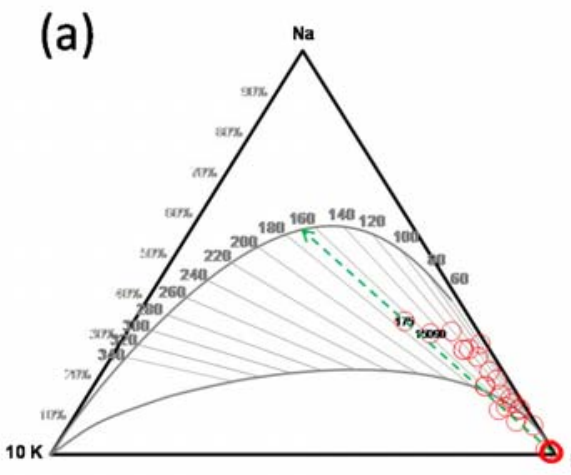

(b)

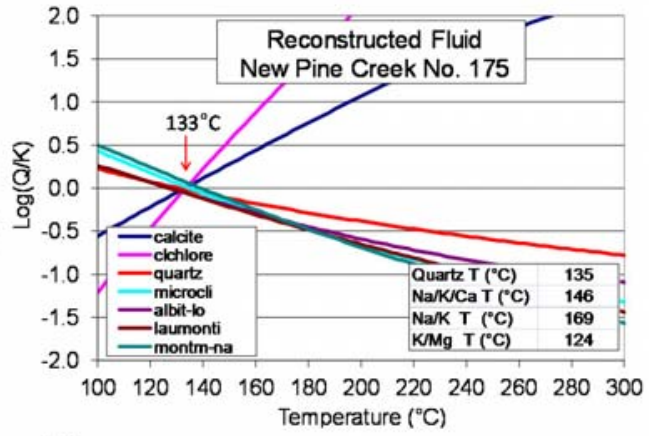

1000

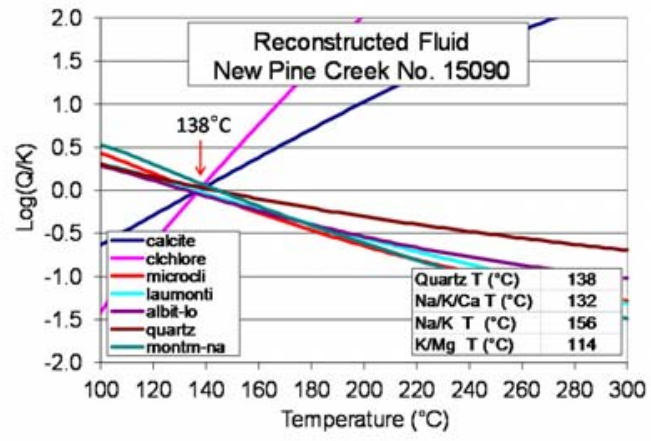


(a)

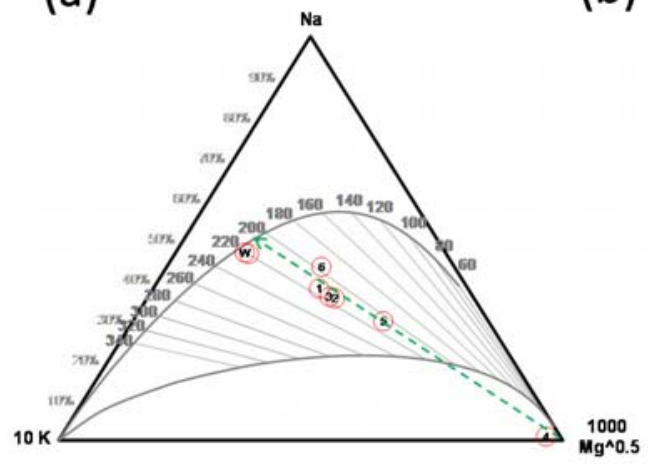

(b)
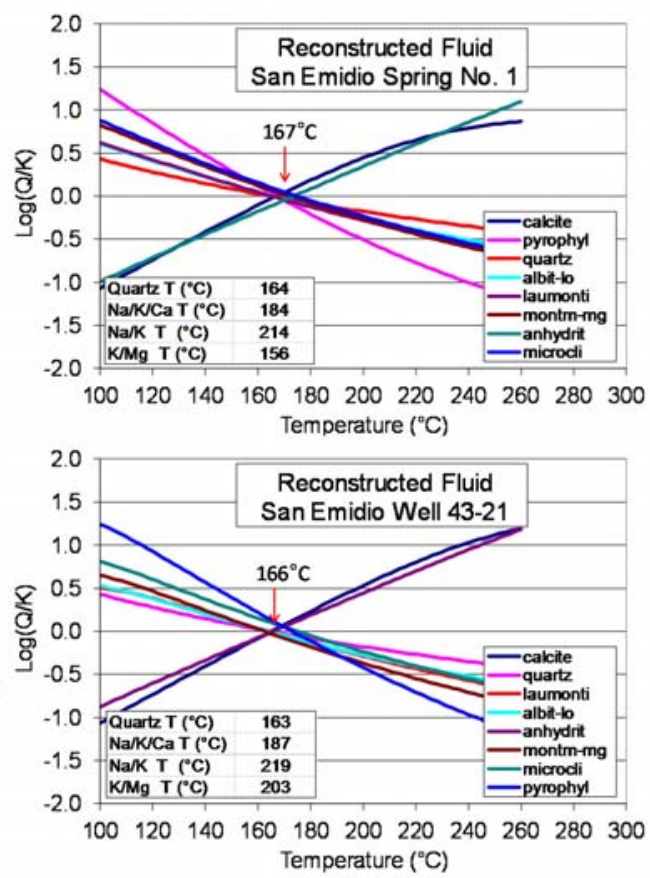


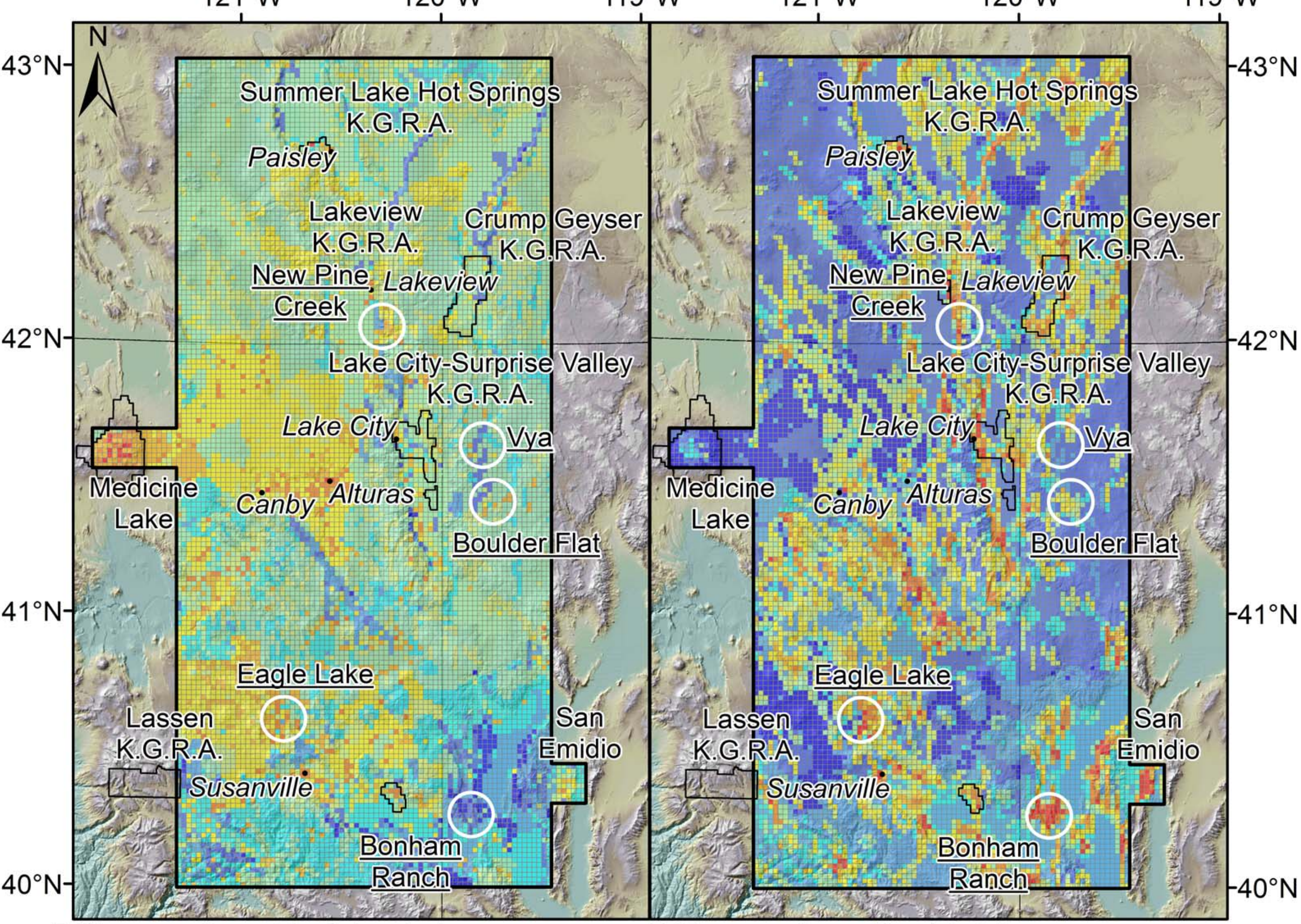

Difference from Medicine Lake

Difference from San Emidio

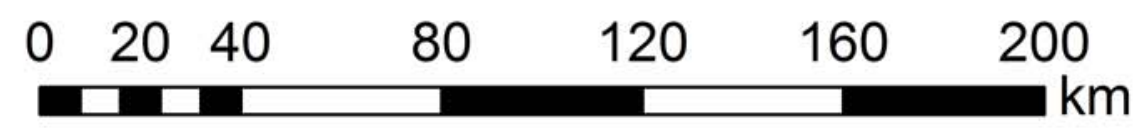




\section{PROXY}

CELL SELECTION

Sum in cell

Fault Length (m)

Fault Age

Dilation Tendency

Slip Tendency

Number of

favorable settings

Strain Rate

Total seismic moment

Age and type of Volcanism

Smoothed Heat flow

Maximum

measured Temp ${ }^{\circ} \mathrm{C}$

Maximum

measured heat flow $\mathrm{mW} / \mathrm{m}^{2}$

Maximum

measured

temperature

gradient $(\mathrm{C} / \mathrm{km})$

Geothemometry

$\mathrm{Na} / \mathrm{K}(\mathrm{SiO} 2, \mathrm{~K} / \mathrm{Mg})$
Youngest in cell

Maximum Dilation

Tendency in cell

Maximum Slip

Tendency in cell

Structural setting were

picked with $2 \mathrm{~km}$

Mean 2nd invariant

stress tensor from

Kreemer et al., 2012

Sum of seismic moment of all EQs in cell

Youngest and/most

felsic in cell

Mean value for heat flow in cell

Maximum measured

temp in cell/well depth

Maximum measured

heat flow in cell

Maximum measured temperature gradient in cell

Maximum calculated temp in cell
Membership function details

Histogram of $\log _{(10)}$ (fault length) used to define fuzzy

numbers for short, medium, and long

Ranked 0-1: $>150=1,>15,000=0.8,>130,000=0.6$,

$>750,00=0.4,>1,600,000=0.2$, no data $=0$ used to define

fuzzy numbers for old, medium, and young

Histogram of unadjusted data values used to define fuzzy numbers for high, medium, and low stress

Histogram of unadjusted data values used to define fuzzy

numbers for high, medium, and low stress

Binary yes favorable structural setting or no favorable structural setting used to define fuzzy numbers

Histogram of $\log _{(10)}$ (2nd invariant strain-rate tensor) used to define fuzzy numbers for high, medium, and low

Histogram of $\log _{(10)}$ (total seismic moment) used to define fuzzy numbers for high, medium, and low

Ranked 0-1: Holocene Both =0.9, Holocene Mafic=0.8, Pleistocene Felsic $=0.7$ Pleistocene Both $=0.6$, Pleistocene Mafic 0.5, Quaternary/Tertiary Felsic $=0.4$,

Quaternary/Tertiary Both $=0.3$, Quaternary/Tertiary Mafic $=0.2$, no data $=0$ used to define fuzzy numbers for high, medium, and low heat associated with magmatism Histogram of unadjusted data values used to define fuzzy numbers for high, medium, and low stress

Histogram of unadjusted data values used to define fuzzy numbers for high, medium, and low heat

Histogram of unadjusted data values used to define fuzzy numbers for high, medium, and low heat

Histogram of unadjusted data values used to derive pseudo-heat flow based on linear relationship between heat flow and TG in Modoc data

Histogram of unadjusted data values used to define fuzzy numbers for high, medium, and low heat 